\title{
Seasonal variations of diacids, ketoacids, and $\alpha$-dicarbonyls in aerosols at Gosan, Jeju Island, South Korea: Implications for sources, formation, and degradation during long-range transport
}

\author{
Shuvashish Kundu, ${ }^{1,2}$ Kimitaka Kawamura, ${ }^{1}$ and Meehye Lee ${ }^{3}$ \\ Received 29 January 2010; revised 11 June 2010; accepted 21 June 2010; published 7 October 2010.
}

[1] Aerosol samples $(n=84)$ were collected continuously from April 2003 to April 2004 at Gosan site in Jeju Island, South Korea. The samples were analyzed for diacids, ketoacids, and $\alpha$-dicarbonyls, as well as organic carbon (OC), elemental carbon (EC), water-soluble organic carbon (WSOC), and water-soluble inorganic ions. Oxalic acid $\left(\mathrm{C}_{2}\right)$ was the most abundant followed by malonic acid $\left(\mathrm{C}_{3}\right)$ in all the seasons. The mean concentration $\left(784 \mathrm{ng} \mathrm{m}^{-3}\right)$ of total diacids $\left(\mathrm{C}_{2}-\mathrm{C}_{12}\right)$ and their relative abundances in total organic species detected, OC and WSOC were found to be the highest in summer, whereas those of ketoacids and dicarbonyls were the highest in winter. The annual mean contributions of diacids, ketoacids, and dicarbonyls to WSOC are 12,1 , and $0.4 \%$, respectively. They are several times higher than those reported in East Asia from which air masses are transported to Gosan, indicating an importance of photochemical processing of aerosols during a long-range transport. Diacids and related compounds show different seasonal variations, suggesting their season-specific sources and photochemical processing. This study demonstrates an enhanced photochemical production and degradation of water-soluble organics in summer. In contrast, higher positive correlations between combustion tracers (non-sea-salt $\mathrm{K}^{+}$and EC) and diacids and related compounds were observed in the winter, pointing out higher emission of diacids and related compounds or their precursors from fossil fuel/biomass burning.

Citation: Kundu, S., K. Kawamura, and M. Lee (2010), Seasonal variations of diacids, ketoacids, and $\alpha$-dicarbonyls in aerosols at Gosan, Jeju Island, South Korea: Implications for sources, formation, and degradation during long-range transport, J. Geophys. Res., 115, D19307, doi:10.1029/2010JD013973.

\section{Introduction}

[2] The ubiquitous presence of diacids and related compounds (ketoacids and $\alpha$-dicarbonyls) in tropospheric aerosols has been well documented in the literature [Kawamura and Ikushima, 1993; Kawamura and Usukura, 1993; Li and Winchester, 1993; Khwaja, 1995; Baboukas et al., 2000; Kerminen et al., 2000; Limbeck et al., 2001; Fraser et al., 2002; Mochida et al., 2003a, 2003b; Ho et al., 2007; Legrand et al., 2007; Miyazaki et al., 2009]. They can account for $0.3-4.5 \%$ of total carbon (TC) in urban aerosols and more than $10 \%$ of TC and water-soluble organic carbon (WSOC) in remote marine aerosols [Kawamura and Ikushima, 1993; Kawamura and Sakaguchi, 1999;

\footnotetext{
${ }^{1}$ Institute of Low Temperature Science, Hokkaido University, Sapporo, Japan.

${ }^{2}$ Graduate School of Environmental Science, Hokkaido University, Sapporo, Japan.

${ }^{3}$ Department of Earth and Environmental Sciences, Korea University, Seoul, South Korea.

Copyright 2010 by the American Geophysical Union. 0148-0227/10/2010JD013973
}

Kerminen et al., 2000; Kawamura and Yasui, 2005; Ho et al., 2007; Wang et al., 2006]. These studies demonstrated that diacids are the major organic species in atmospheric aerosols, although their seasonal behaviors are not well understood.

[3] Pradeep et al. [2003] reported that oxalic, malonic, and glutaric acids are fully activated to cloud droplets at supersaturation, being consistent with the experiments of Cruz and Pandis [1997]. They observed that submicron aerosols of glutaric and adipic acids can act as cloud condensation nuclei at typical atmospheric supersaturations of $0.3 \%$ and $1 \%$. Diacids can also affect the heterogeneous chemistry in the atmosphere. For example, Folkers et al. [2003] reported that the reactive uptake coefficient of $\mathrm{N}_{2} \mathrm{O}_{5}$, one of major intermediates for the removal of $\mathrm{NO}_{\mathrm{x}}$ in the atmosphere, by uncoated $\mathrm{NH}_{4} \mathrm{HSO}_{4}$ particles is depressed when $\mathrm{NH}_{4} \mathrm{HSO}_{4}$ is coated with organics containing diacids and others. This suggests that an organic surface suppresses the transfer of $\mathrm{N}_{2} \mathrm{O}_{5}$ into the ammonium bisulfate core. The higher levels of $\mathrm{N}_{2} \mathrm{O}_{5}$ increase the oxidizing capacity of the atmosphere. It is therefore very important to study diacids and related compounds in atmospheric aerosols. 


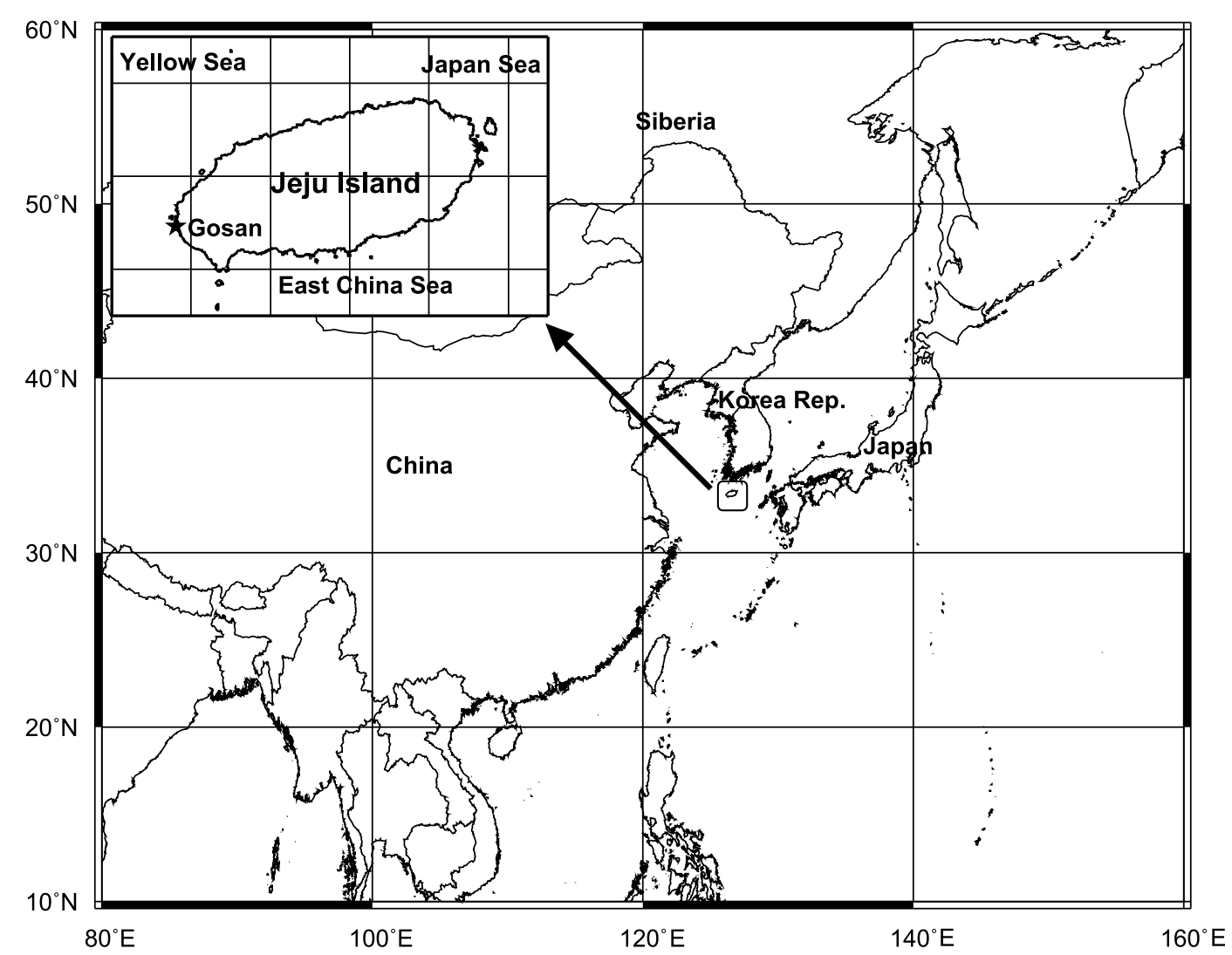

Figure 1. Map showing geographical region where sampling was carried out. The Gosan site is situated in the west coast of Jeju Island, South Korea.

[4] Diacids and related compounds do have primary sources, such as fossil fuel combustion [Kawamura and Kaplan, 1987], meat cooking operation [Rogge et al., 1991; Schauer et al., 1999], and biomass burning [Yamasoe et al., 2000; Mayol-Bracero et al., 2002; Gao et al., 2003; Kundu et al., 2010a]. However, it is widely believed, based on laboratory and field observations, that they are overwhelmingly produced due to the oxidation of various organic precursors via different photochemical pathways in the atmosphere.

[5] Matsunaga et al. [1999] reported that an irradiated oleic acid-ozone system produces a homologous series of diacids $\left(\mathrm{C}_{2}-\mathrm{C}_{9}\right)$ with azelaic acid as dominant species. A cycloalkene-ozone system can produce diacids via the transformation of dialdehydes to oxoacids [Hatakeyama et al., 1985; Kalberer et al., 2000; Gao et al., 2001]. Warneck [2003] suggested that cloud processing of glyoxal and glycoaldehyde yields oxalic acid via glyoxylic acid. Glyoxal can be produced from toluene and other aromatic hydrocarbons, ethyne, and isoprene [Stockwell et al., 1997; Warneck, 2003; Ervens et al., 2004; Ieda et al., 2006], whereas glycoaldehyde is from ethene and isoprene [Warneck, 2003; Ervens et al., 2004; Ieda et al., 2006]. Lim et al. [2005] and Carlton et al. [2006] suggested that oxalic acid is produced from the oxidation of methylglyoxal via the formation of pyruvic and acetic acids as intermediates. Fisseha et al. [2004] reported that photooxidation of 1, 3, 5-trimethylbenzene can produce oxalic, methylmaleic, and pyruvic acids. Phthalic acid is a photodegradation product of naphthalene [Bunce et al., 1997] and possibly other polycyclic aromatic hydrocarbons [Jang and McDow, 1997].

[6] Diurnal variations of diacids and related compounds have been reported in aerosol samples with maxima at noontime [Satsumabayashi et al., 1990; Stephanou and Stratigakis, 1993; Kawamura and Yasui, 2005]. Diacids are enriched in the submicron mode of aerosols [Mészáros et al., 1997; Kerminen et al., 1999, 2000]. Kawamura et al. [1995] reported that concentrations of diacids are 520 times more abundant in Arctic aerosols during polar sunrise season than those in aerosols during the preceding dark winter months. These studies provide strong evidence for the secondary production of diacids and related compounds.

[7] Gosan site, which is located at the western edge of Jeju Island, South Korea, has been regarded as an ideal place to study the chemical production and transformation of atmospheric organic aerosol from anthropogenic and biogenic (oceanic and continental) precursors, whose emission strengths vary due to the air masses transported from China, Korea, Japan, and the Pacific Ocean. Air mass transport patterns depend on the seasons. Previous studies at the Gosan site have determined inorganics, bulk organics, and trace gases in the atmosphere over short and long timescales [Carmichael et al., 1996, 1997; Arimoto et al., 1997; Chen et al., 1997; Kim et al., 2002, 2007; Park et al., 2004; Topping et al., 2004; Lee et al., 2007; Miyazaki et al., 2007]. 
Table 1. Concentrations of Diacids, Ketoacids, and $\alpha$-Dicarbonyls Detected in Atmospheric Aerosols Over Gosan, Jeju Island, South Korea

\begin{tabular}{|c|c|c|c|c|c|c|c|c|c|c|c|c|}
\hline \multirow[b]{2}{*}{ Compounds } & \multicolumn{3}{|c|}{ Spring $(n=37)^{\mathrm{a}}$} & \multicolumn{3}{|c|}{ Summer $(n=13)^{\mathbf{a}}$} & \multicolumn{3}{|c|}{ Autumn $(n=10)^{\mathrm{a}}$} & \multicolumn{3}{|c|}{ Winter $(n=24)^{\mathrm{a}}$} \\
\hline & $\begin{array}{c}\text { Range } \\
\left(\mathrm{ng} \mathrm{m}^{-3}\right)\end{array}$ & $\begin{array}{l}\text { Average } \\
\left(\mathrm{ng} \mathrm{m}^{-3}\right)\end{array}$ & $\begin{array}{c}\text { Median } \\
\left(\mathrm{ng} \mathrm{m}^{-3}\right)\end{array}$ & $\begin{array}{l}\text { Range } \\
\left(\mathrm{ng} \mathrm{m}^{-3}\right)\end{array}$ & $\begin{array}{l}\text { Average } \\
\left(\mathrm{ng} \mathrm{m}^{-3}\right)\end{array}$ & $\begin{array}{c}\text { Median } \\
\left(\mathrm{ng} \mathrm{m}^{-3}\right)\end{array}$ & $\begin{array}{c}\text { Range } \\
\left(\mathrm{ng} \mathrm{m}^{-3}\right)\end{array}$ & $\begin{array}{l}\text { Average } \\
\left(\mathrm{ng} \mathrm{m}^{-3}\right)\end{array}$ & $\begin{array}{l}\text { Median } \\
\left(\mathrm{ng} \mathrm{m}^{-3}\right)\end{array}$ & $\begin{array}{c}\text { Range } \\
\left(\mathrm{ng} \mathrm{m}^{-3}\right)\end{array}$ & $\begin{array}{l}\text { Average } \\
\left(\mathrm{ng} \mathrm{m}^{-3}\right)\end{array}$ & $\begin{array}{c}\text { Median } \\
\left(\mathrm{ng} \mathrm{m}^{-3}\right)\end{array}$ \\
\hline \multicolumn{13}{|l|}{ Saturated $n$-diacids } \\
\hline Oxalic, $\mathrm{C}_{2}$ & $198-1228$ & 537.0 & 471.0 & $201-1293$ & 564.4 & 478.2 & $189.2-775$ & 381.9 & 350.0 & $92.3-1251$ & 349.2 & 272.8 \\
\hline Malonic, $\mathrm{C}_{3}$ & $12-166$ & 64.8 & 54.0 & $7-167$ & 73.3 & 72.1 & $20.2-118$ & 54.3 & 49.0 & $10.1-129$ & 40.9 & 32.2 \\
\hline Succinic, $\mathrm{C}_{4}$ & $8-190$ & 59.3 & 43.5 & $10-187$ & 68.8 & 62.2 & $7.1-68.6$ & 30.9 & 22.0 & $8.7-118$ & 33.1 & 26.0 \\
\hline Glutaric, $\mathrm{C}_{5}$ & $1.4-65$ & 16.5 & 12.3 & $2.1-69$ & 17.9 & 12.5 & $0.9-17.5$ & 7.9 & 6.0 & $2.8-41$ & 9.5 & 7.2 \\
\hline Adipic, $\mathrm{C}_{6}$ & $0.7-19$ & 5.6 & 4.8 & $0.9-18$ & 4.9 & 2.5 & $0.6-7$ & 3.7 & 3.3 & $1.6-18.1$ & 4.8 & 3.6 \\
\hline Pimelic, $\mathrm{C}_{7}$ & $0.2-8$ & 2.3 & 1.8 & $0.1-9.4$ & 2.2 & 1.0 & $0.4-2.9$ & 1.4 & 1.4 & $0.4-11.2$ & 2.2 & 1.7 \\
\hline Suberic, $\mathrm{C}_{8}$ & $0.7-6$ & 2.2 & 1.9 & $0.7-8.3$ & 2.5 & 1.8 & $0.6-2.6$ & 1.6 & 1.5 & $0.01-9.1$ & 1.9 & 1.5 \\
\hline Azelaic, $\mathrm{C}_{9}$ & $1.3-7.6$ & 4.3 & 4.1 & $2-9$ & 4.6 & 4.1 & $2.2-6.2$ & 3.9 & 3.5 & $0.01-12.6$ & 3.4 & 3.3 \\
\hline Sebacic, $C_{10}$ & $0.02-4.1$ & 0.9 & 0.8 & $0.4-2.5$ & 0.9 & 0.6 & $0.1-1.1$ & 0.5 & 0.4 & $0.1-2.8$ & 0.6 & 0.5 \\
\hline Undecanedioic, $\mathrm{C}_{11}$ & $0.4-4.9$ & 1.2 & 1.0 & $0.5-9$ & 3.3 & 3.2 & $0.7-2$ & 1.2 & 1.1 & $0.2-3.3$ & 0.8 & 0.5 \\
\hline Dodecanedioic, $\mathrm{C}_{12}$ & $0.01-0.2$ & 0.1 & 0.1 & $\mathrm{BDL}^{\mathrm{a}}-0.4$ & 0.1 & 0.03 & $0.01-0.1$ & 0.1 & 0.1 & $\mathrm{BDL}^{\mathrm{a}}-0.4$ & 0.1 & 0.1 \\
\hline \multicolumn{13}{|l|}{ Branched diacids } \\
\hline Methylmalonic, $\mathrm{iC}_{4}$ & $0.6-4.9$ & 1.7 & 1.4 & $0.4-4.6$ & 1.8 & 1.7 & $0.3-3.7$ & 1.6 & 1.3 & $0.5-4.2$ & 1.3 & 1.1 \\
\hline Methylsuccinic, $\mathrm{iC}_{5}$ & $0.6-10.2$ & 3.7 & 3.0 & $0.3-10.6$ & 3.5 & 2.4 & $0.2-5.8$ & 2.1 & 1.8 & $1.3-11.9$ & 3.6 & 2.7 \\
\hline Methylglutaric, $\mathrm{iC}_{6}$ & $0.1-5.2$ & 1.2 & 0.8 & $0.1-4.7$ & 1.0 & 0.9 & $0.1-1.4$ & 0.6 & 0.5 & $0.5-2.6$ & 0.9 & 0.8 \\
\hline \multicolumn{13}{|l|}{ Unsaturated diacids } \\
\hline Maleic, M & $0.1-10.9$ & 3.7 & 3.0 & $0.6-6.6$ & 2.3 & 1.9 & $0.5-7.4$ & 3.1 & 3.1 & $2.2-12.8$ & 4.9 & 4.0 \\
\hline Fumaric, F & $0.4-9.2$ & 3.2 & 2.3 & $0.7-9.9$ & 3.2 & 2.6 & $0.5-4.1$ & 2.1 & 2.1 & $0.7-11.5$ & 2.7 & 1.9 \\
\hline Methylmaleic, mM & $0.2-5.9$ & 2.6 & 2.4 & $0.5-6.1$ & 1.9 & 1.3 & $0.3-6$ & 2.6 & 2.5 & $0.9-12.1$ & 3.4 & 2.4 \\
\hline Phthalic, Ph & $1-19.9$ & 7.9 & 7.4 & $0.5-15.5$ & 4.9 & 2.9 & $1.4-38.3$ & 9.6 & 8.2 & $0.5-52.4$ & 19.4 & 15.0 \\
\hline Isophthalic, $\mathrm{iPh}$ & $0.2-2.7$ & 1.2 & 1.1 & $0.1-3.8$ & 0.8 & 0.4 & $0.01-2$ & 0.8 & 0.8 & $0.3-5.2$ & 1.5 & 1.1 \\
\hline Terephthalic, $\mathrm{tPh}$ & $0.01-17$ & 8.0 & 8.4 & $1.4-17$ & 6.7 & 5.5 & $2.6-13.4$ & 8.6 & 9.1 & $3-30$ & 8.9 & 7.6 \\
\hline \multicolumn{13}{|l|}{ Multifunctional diacids } \\
\hline Hydroxysuccinic, $\mathrm{hC}_{4}$ & $\mathrm{BDL}^{\mathrm{a}}-15$ & 3.0 & 2.2 & $0.6-21.1$ & 7.4 & 6.4 & $0.5-13$ & 4.2 & 2.7 & $0.5-11.8$ & 2.6 & 2.0 \\
\hline Ketomalonic, $\mathrm{kC}_{3}$ & $0.1-4$ & 1.2 & 1.0 & $0.1-1.7$ & 0.7 & 0.4 & $0.1-1.8$ & 0.8 & 0.9 & $0.6-6$ & 2.1 & 1.5 \\
\hline Ketopimelic, $\mathrm{kC}_{7}$ & $0.01-20$ & 4.0 & 2.0 & $0.6-20.8$ & 6.8 & 3.9 & $0.4-5.2$ & 1.9 & 1.4 & $0.2-4.9$ & 1.4 & 1.1 \\
\hline Total diacids & $233-1730$ & 735.4 & 630.4 & $253-1875$ & 784.0 & 623.4 & $245-1062$ & 525.3 & 461.6 & $142-1757$ & 499.1 & 392.4 \\
\hline \multicolumn{13}{|l|}{ Ketoacids } \\
\hline Glyoxylic, $\omega \mathrm{C}_{2}$ & $7.3-103.4$ & 38.0 & 31.4 & $6.3-84.8$ & 28.5 & 17.7 & $6.3-63.8$ & 27.8 & 23.8 & $11.2-148.2$ & 40.7 & 34.5 \\
\hline 3-Oxopropanoic, $\omega \mathrm{C}_{3}$ & $0.01-2.0$ & 0.4 & 0.2 & $0.02-4.2$ & 1.4 & 0.5 & $0.01-0.4$ & 0.1 & 0.1 & $0.1-0.6$ & 0.2 & 0.2 \\
\hline 4-Oxobutanoic, $\omega \mathrm{C}_{4}$ & $0.004-3.7$ & 0.7 & 0.3 & $0.1-0.9$ & 0.4 & 0.4 & $\mathrm{BDL}^{\mathrm{a}}-2.9$ & 0.6 & 0.3 & $0.1-1.6$ & 0.3 & 0.2 \\
\hline 9-Oxononanoic, $\omega \mathrm{C}_{9}$ & $\mathrm{BDL}^{\mathrm{a}}-5.3$ & 1.9 & 1.8 & $\mathrm{BDL}^{\mathrm{a}}-4.7$ & 1.1 & 0.6 & $0.8-4.5$ & 2.0 & 1.9 & $\mathrm{BDL}^{\mathrm{a}}-5.7$ & 1.3 & 0.7 \\
\hline Pyruvic acid, Pyr & $0.54-13.4$ & 5.0 & 4.9 & $0.9-12.1$ & 4.3 & 2.7 & $0.8-5.5$ & 3.0 & 3.0 & $0.7-15$ & 4.6 & 3.2 \\
\hline Total ketoacids & $9.7-120.3$ & 46.1 & 39.7 & $9-103$ & 35.7 & 22.3 & $8-73.9$ & 33.5 & 29.0 & $12.8-170.4$ & 47.3 & 39.5 \\
\hline Glyoxal, Gly & $1.1-11.6$ & 3.6 & 3.3 & $0.5-4.7$ & 2.0 & 1.2 & $0.4-6.9$ & 2.2 & 1.6 & $2.2-106.3$ & 9.3 & 4.7 \\
\hline Methylglyoxal, MeGly & $0.9-60$ & 14.4 & 11.0 & $1.9-15.6$ & 7.1 & 7.2 & $4.6-21.7$ & 9.2 & 7.0 & $1.7-35.7$ & 13.8 & 13.5 \\
\hline Total $\alpha$-dicarbonyls & $2-64$ & 17.9 & 14.4 & $2.3-20.3$ & 9.1 & 8.3 & $6-28.6$ & 11.4 & 8.9 & $8.1-108.2$ & 23.1 & 17.1 \\
\hline
\end{tabular}

${ }^{\text {a}}$ Spring, March to May; summer, June to August; autumn, September to November; winter, December to February; $n$, number of samples; BDL, below detection limit.

However, there are a few studies on molecular composition of atmospheric organic aerosols [Kawamura et al., 2004; Yang et al., 2004; Wang et al., 2009]. These studies, except for the work of Kawamura et al. [2004], mainly focused on the spring samples, when the continental outflows are the most intense. Kawamura et al. [2004] discussed composition and seasonal variations of diacids and related compounds in atmospheric aerosol samples $(n=48)$ collected from April 2001 to March 2002. There are a few ground, ship, and aircraft measurements of diacids and related compounds in the regions surrounding the Gosan site, such as East Asian megacities, the Japan Sea, the China Sea, the Pacific Ocean, and Chichi-jima Island [Kawamura et al., 2003; Mochida et al., 2003a, 2003b; Ho et al., 2007].

[8] In this study, we report molecular distributions, abundances, and seasonal trends of diacids and related compounds in atmospheric aerosol samples $(n=84)$ collected at Gosan from April 2003 to April 2004 and compare our data with previous studies carried out at the same site and its surrounding areas to understand any significant organic composition changes in East Asia. We also discuss the sources and chemical formation and loss of diacids and related compounds during long-range transport.

\section{Experiment}

\subsection{Site Description}

[9] The Gosan site in Jeju Island $\left(33^{\circ} 29^{\prime} \mathrm{N}, 126^{\circ} 16^{\prime} \mathrm{E}\right)$ is approximately $100 \mathrm{~km}$ south of Korean Peninsula, $\sim 500 \mathrm{~km}$ east of China (Jiangsu province or Shanghai), $\sim 200 \mathrm{~km}$ west of Kyushu Island, Japan, and $\sim 1000 \mathrm{~km}$ northeast of Taipei (Figure 1). The site and its surroundings are covered with grasses but no trees. Because of its location and very limited local anthropogenic emissions [Kim et al., 1998], Gosan has been considered as an ideal site to monitor the air quality of the western rim of the North Pacific and the outflows from East Asia [Carmichael et al., 1996, 1997; Chen et al., 1997]. Gosan was used as a supersite of the Asian Pacific Regional 


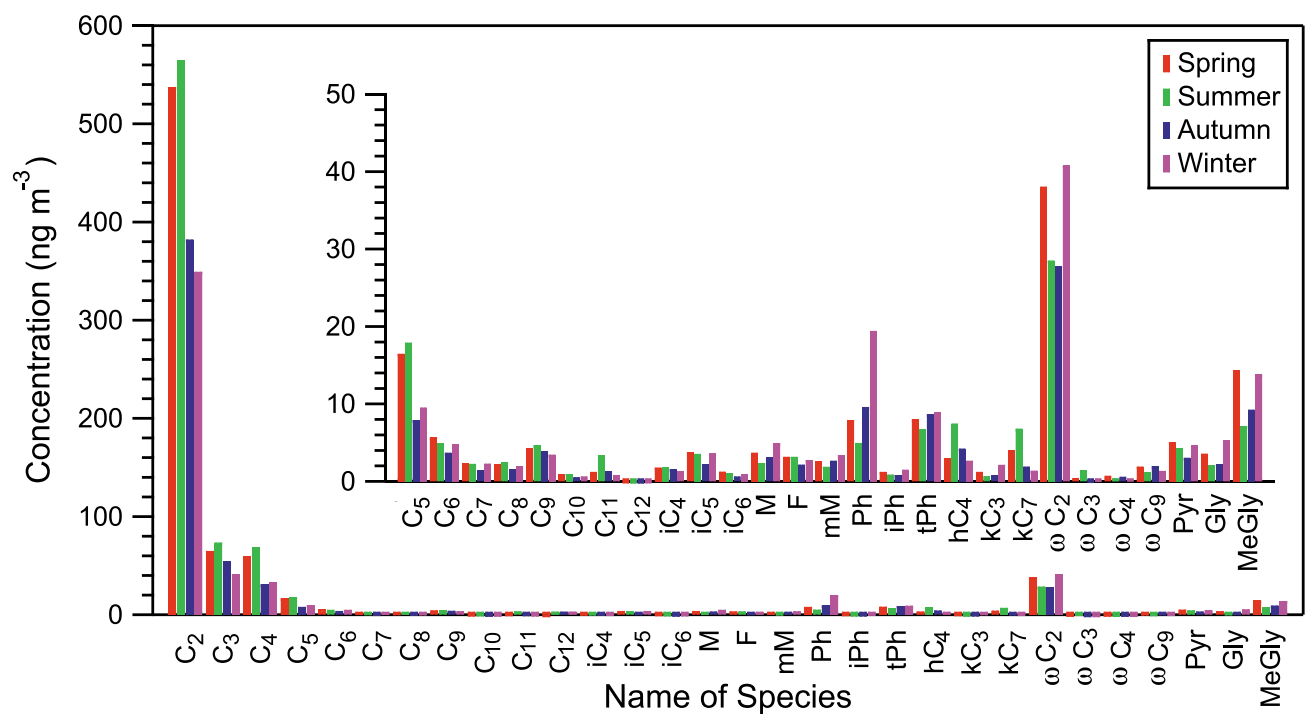

Figure 2. Seasonally averaged molecular distribution of straight chain diacids $\left(\mathrm{C}_{2}-\mathrm{C}_{12}\right)$, branched chain diacids $\left(\mathrm{iC}_{4}-\mathrm{iC}_{6}\right)$, unsaturated diacids $(\mathrm{M}, \mathrm{F}, \mathrm{mM}, \mathrm{Ph}, \mathrm{Ph}$ and $\mathrm{tPh})$, multifunctional diacids $\left(\mathrm{hC}_{4}, \mathrm{kC}_{3}\right.$ and $\mathrm{kC}_{7}$ ), ketoacids ( $\omega \mathrm{C}_{2}-\omega \mathrm{C}_{9}$, and Pyr), and $\alpha$-dicarbonyls (Gly and MeGly) in aerosol collected at Gosan from April 2003 to April 2004. See Table 1 for abbreviations.

Aerosol Characterization Experiment (ACE-Asia) campaign in 2001 [Huebert et al., 2003] and the Pacific Exploratory Mission (PEM)-West A and PEM-West B programs conducted between 1991 and 1994 [Hoell et al., 1996, 1997]. It is now used as one of superstations of Atmospheric Brown Cloud program [Lee et al., 2007]. A more detailed description of this site is given elsewhere [Kim et al., 1998; Kawamura et al., 2004; Lee et al., 2007].

\subsection{Aerosol Sampling}

[10] Total suspended particles (TSP) in the atmosphere were collected at the Gosan site over 2-7 days throughout the year from 2003 April to 2004 April. TSP samples $(n=$ 84) were collected onto precombusted quartz fiber filters $(20 \times 25 \mathrm{~cm}$, Pallflex 2500QAT-UP) using a high-volume air sampler (Kimoto AS-810) at a flow rate of $0.8 \mathrm{~m}^{-3} \mathrm{~min}^{-1}$. The sampler was placed on the roof of a trailer house $(\sim 3 \mathrm{~m}$ above the ground). TSP sampling is preferred for collecting adequate aerosol materials in order to measure diacids and related compounds and a wide variety of chemical components (water-soluble inorganic ions, organic carbon (OC), elemental carbon (EC), WSOC, etc.). Before and after the sampling, each filter was placed in a clean glass jar $(150 \mathrm{~mL})$ with a Teflon-lined screw cap. Samples were stored immediately in a freezer after the collection, transported to our laboratory in Sapporo at ambient temperatures, and stored in a dark freezer room at $-20^{\circ} \mathrm{C}$ until analysis. High-volume sampling has potential problems: (1) adsorption of gaseous diacids and related compounds onto filter substrates and already collected particles and (2) volatilization of particulate diacids and related compounds during sampling. Mochida et al. [2003b] compared the concentrations of diacids (oxalic, malonic, succinic, and glutaric acids) obtained using highvolume and annular denuder samplers. Annular denuder system has negligible adsorption/volatilization problems in the measurement of particulate diacids. An agreement was observed between high-volume and denuder data [Mochida et al., 2003b]. Limbeck et al. [2001] observed the dominant fraction of diacids $\left(\mathrm{C}_{2}-\mathrm{C}_{9}\right)$ and related compounds (pyruvic and glyoxylic acids) in the aerosol phase. This result has suggested that high-volume data represent real ambient concentration of particulate diacids and related compounds. Field blank filters were collected every month like the real samples except that the pump was not turned on.

\subsection{Analytical Method}

[11] Filter samples were analyzed for water-soluble diacids, ketoacids, and $\alpha$-dicarbonyls using the method described by Kawamura and Ikushima [1993] and Kawamura [1993]. Briefly, aliquots of the filter samples were extracted with organic-free pure water $(5 \mathrm{~mL} \times 3$, $>18 \mathrm{M} \Omega$ ) by ultrasonic agitation for the isolation of diacids and related compounds. The extracts were passed through a glass column (Pasteur pipette) packed with quartz wool in order to remove filter debris and insoluble particles and then concentrated to almost dryness using a rotary evaporator $\left(\sim 40^{\circ} \mathrm{C}\right)$. The concentrates were derivatized with $14 \%$ borontrifluoride in $n$-butanol at $100^{\circ} \mathrm{C}$ over an hour. The derived dibutyl esters and dibutoxy acetals were extracted with $n$-hexane $(\sim 5 \mathrm{~mL})$ after adding pure water $(\sim 5 \mathrm{~mL})$. The hexane layer was concentrated to $\sim 50 \mu \mathrm{L}$ using a rotary evaporator, transferred to small vial $(1.5 \mathrm{~mL})$, dried to almost dryness by $\mathrm{N}_{2}$ blow down, and dissolved in a known volume of $n$-hexane (usually $100-400 \mu \mathrm{L}$ ). This analytical technique may provide some artifacts due to chemical treatment of aerosols [Hallquist et al., 2009]. For example, oligomers of glyoxal and methylglyoxal in aerosols can be broken down to monomers during the derivatization step, which results in higher concentrations of $\alpha$-dicarbonyls than reality. Although this artifact has not been evaluated in the present study, we consider that the reported concentrations of glyoxal and methylglyoxal include their oligomers.

[12] A $2 \mu \mathrm{L}$ aliquot of the sample was injected into a capillary gas chromatography (GC) system (Hewlett- 
Table 2. Relative Abundances of Individual Compounds in Total Diacids, Ketoacids, and $\alpha$-Dicarbonyls in Aerosols

\begin{tabular}{|c|c|c|c|c|c|c|c|c|c|c|c|c|}
\hline \multirow[b]{2}{*}{ Compounds } & \multicolumn{3}{|c|}{ Spring $(n=37)^{\mathrm{a}}$} & \multicolumn{3}{|c|}{ Summer $(n=13)^{\mathrm{a}}$} & \multicolumn{3}{|c|}{ Autumn $(n=10)^{\mathrm{a}}$} & \multicolumn{3}{|c|}{ Winter $(n=24)^{\mathrm{a}}$} \\
\hline & $\begin{array}{c}\text { Minimum } \\
(\%)\end{array}$ & $\begin{array}{l}\text { Maximum } \\
(\%)\end{array}$ & $\begin{array}{c}\text { Average } \\
(\%)\end{array}$ & $\begin{array}{c}\text { Minimum } \\
(\%)\end{array}$ & $\begin{array}{c}\text { Maximum } \\
(\%)\end{array}$ & $\begin{array}{c}\text { Average } \\
(\%)\end{array}$ & $\begin{array}{c}\text { Minimum } \\
(\%)\end{array}$ & $\begin{array}{l}\text { Maximum } \\
(\%)\end{array}$ & $\begin{array}{c}\text { Average } \\
(\%)\end{array}$ & $\begin{array}{c}\text { Minimum } \\
(\%)\end{array}$ & $\begin{array}{l}\text { Maximum } \\
(\%)\end{array}$ & $\begin{array}{c}\text { Average } \\
(\%)\end{array}$ \\
\hline \multicolumn{13}{|l|}{ Saturated $n$-diacids } \\
\hline Oxalic, $\mathrm{C}_{2}$ & 53.54 & 80.95 & 67.60 & 64.35 & 81.00 & 70.77 & 56.58 & 75.62 & 67.14 & 53.88 & 70.97 & 61.25 \\
\hline Malonic, $\mathrm{C}_{3}$ & 4.11 & 11.12 & 8.14 & 1.37 & 11.03 & 8.67 & 6.75 & 13.11 & 9.31 & 5.39 & 9.17 & 7.17 \\
\hline Succinic, $\mathrm{C}_{4}$ & 3.18 & 10.78 & 6.96 & 3.14 & 10.81 & 7.10 & 2.72 & 6.68 & 5.15 & 4.78 & 6.54 & 5.70 \\
\hline Glutaric, $\mathrm{C}_{5}$ & 0.48 & 3.49 & 1.82 & 0.72 & 3.44 & 1.72 & 0.35 & 1.81 & 1.27 & 1.19 & 2.08 & 1.62 \\
\hline Adipic, $\mathrm{C}_{6}$ & 0.30 & 1.18 & 0.69 & 0.25 & 0.89 & 0.50 & 0.23 & 0.91 & 0.65 & 0.49 & 1.10 & 0.86 \\
\hline Pimelic, $\mathrm{C}_{7}$ & 0.06 & 0.43 & 0.27 & 0.03 & 0.47 & 0.22 & 0.16 & 0.38 & 0.25 & 0.11 & 0.57 & 0.36 \\
\hline Suberic, $\mathrm{C}_{8}$ & 0.10 & 0.46 & 0.27 & 0.19 & 0.48 & 0.29 & 0.20 & 0.36 & 0.28 & 0.003 & 0.46 & 0.33 \\
\hline Azelaic, $\mathrm{C}_{9}$ & 0.26 & 1.20 & 0.60 & 0.37 & 1.20 & 0.65 & 0.55 & 1.15 & 0.75 & 0.005 & 1.20 & 0.63 \\
\hline Sebacic, $C_{10}$ & 0.005 & 0.42 & 0.10 & 0.06 & 0.20 & 0.12 & 0.02 & 0.13 & 0.09 & 0.06 & 0.18 & 0.10 \\
\hline Undecanedioic, $\mathrm{C}_{11}$ & 0.07 & 0.91 & 0.17 & 0.14 & 0.73 & 0.43 & 0.17 & 0.73 & 0.26 & 0.05 & 0.36 & 0.13 \\
\hline Dodecanedioic, $\mathrm{C}_{12}$ & 0.002 & 0.08 & 0.01 & $\mathrm{BDL}^{\mathrm{a}}$ & 0.02 & 0.01 & 0.004 & 0.02 & 0.01 & $\mathrm{BDL}^{\mathrm{a}}$ & 0.03 & 0.01 \\
\hline \multicolumn{13}{|l|}{ Branched diacids } \\
\hline Methylmalonic, $\mathrm{iC}_{4}$ & 0.12 & 0.41 & 0.22 & 0.10 & 0.29 & 0.21 & 0.12 & 0.32 & 0.25 & 0.14 & 0.43 & 0.24 \\
\hline Methylsuccinic, $\mathrm{iC}_{5}$ & 0.24 & 1.22 & 0.47 & 0.09 & 0.58 & 0.37 & 0.08 & 0.75 & 0.36 & 0.46 & 0.98 & 0.66 \\
\hline Methylglutaric, $\mathrm{iC}_{6}$ & 0.03 & 0.33 & 0.14 & 0.03 & 0.23 & 0.10 & 0.02 & 0.18 & 0.11 & 0.07 & 0.32 & 0.19 \\
\hline \multicolumn{13}{|l|}{ Unsaturated diacids } \\
\hline Maleic, M & 0.02 & 2.54 & 0.51 & 0.13 & 0.34 & 0.26 & 0.11 & 1.37 & 0.60 & 0.35 & 2.13 & 1.04 \\
\hline Fumaric, $\mathrm{F}$ & 0.10 & 0.55 & 0.37 & 0.18 & 0.50 & 0.34 & 0.16 & 0.64 & 0.37 & 0.23 & 0.64 & 0.47 \\
\hline Methylmaleic, mM & 0.09 & 0.96 & 0.33 & 0.13 & 0.30 & 0.20 & 0.08 & 0.87 & 0.48 & 0.23 & 0.88 & 0.61 \\
\hline Phthalic, Ph & 0.15 & 3.37 & 1.06 & 0.20 & 0.93 & 0.54 & 0.41 & 4.91 & 1.75 & 0.08 & 7.47 & 3.68 \\
\hline Isophthalic, iPh & 0.05 & 0.38 & 0.15 & 0.02 & 0.19 & 0.07 & 0.004 & 0.42 & 0.15 & 0.12 & 0.42 & 0.24 \\
\hline Terephthalic, tPh & 0.002 & 2.13 & 1.07 & 0.39 & 1.77 & 0.79 & 1.00 & 3.29 & 1.71 & 0.96 & 2.01 & 1.60 \\
\hline \multicolumn{13}{|l|}{ Multifunctional diacids } \\
\hline Hydroxysuccinic, $\mathrm{hC}_{4}$ & $\mathrm{BDL}^{\mathrm{a}}$ & 0.89 & 0.34 & 0.16 & 1.28 & 0.74 & 0.15 & 1.15 & 0.61 & 0.21 & 0.71 & 0.43 \\
\hline Ketomalonic, $\mathrm{kC}_{3}$ & 0.02 & 0.94 & 0.18 & 0.02 & 0.14 & 0.08 & 0.03 & 0.29 & 0.13 & 0.10 & 1.33 & 0.44 \\
\hline Ketopimelic, $\mathrm{kC}_{7}$ & 0.001 & 1.52 & 0.47 & 0.21 & 1.19 & 0.65 & 0.16 & 0.46 & 0.28 & 0.10 & 0.44 & 0.22 \\
\hline Total diacids & 0.001 & 80.95 & 4.00 & 0.02 & 81.00 & 4.12 & 0.00 & 75.62 & 4.00 & 0.00 & 70.97 & 3.83 \\
\hline \multicolumn{13}{|l|}{ Ketoacids } \\
\hline Glyoxylic, $\omega \mathrm{C}_{2}$ & 2.65 & 6.95 & 4.62 & 1.43 & 4.24 & 3.11 & 2.37 & 8.18 & 4.81 & 4.28 & 10.00 & 7.05 \\
\hline 3-Oxopropanoic, $\omega \mathrm{C}_{3}$ & 0.001 & 0.28 & 0.05 & 0.01 & 0.32 & 0.12 & 0.01 & 0.05 & 0.02 & 0.01 & 0.09 & 0.05 \\
\hline 4-Oxobutanoic, $\omega \mathrm{C}_{4}$ & 0.001 & 0.44 & 0.10 & 0.02 & 0.13 & 0.05 & $\mathrm{BDL}^{\mathrm{a}}$ & 0.93 & 0.13 & 0.01 & 0.22 & 0.05 \\
\hline 9-Oxononanoic, $\omega \mathrm{C}_{9}$ & $\mathrm{BDL}^{\mathrm{a}}$ & 1.24 & 0.26 & $\mathrm{BDL}^{\mathrm{a}}$ & 0.92 & 0.24 & 0.25 & 0.66 & 0.37 & $\mathrm{BDL}^{\mathrm{a}}$ & 0.74 & 0.24 \\
\hline Pyruvic acid, Pyr & 0.13 & 1.03 & 0.60 & 0.24 & 0.78 & 0.47 & 0.24 & 1.39 & 0.57 & 0.33 & 1.40 & 0.74 \\
\hline \multicolumn{12}{|l|}{$\alpha$-Dicarbonyls } & 1.63 \\
\hline Glyoxal, Gly & 0.09 & 2.71 & 0.55 & 0.09 & 0.46 & 0.24 & 0.15 & 1.07 & 0.44 & 0.37 & 4.08 & 1.24 \\
\hline Methylglyoxal & 0.35 & 5.21 & 1.86 & 0.52 & 1.45 & 0.92 & 1.19 & 2.78 & 1.70 & 0.72 & 5.63 & 2.64 \\
\hline Total $\alpha$-dicarbonyls & 0.09 & 5.21 & 1.20 & 0.09 & 1.45 & 0.58 & 0.15 & 2.78 & 1.07 & 0.37 & 5.63 & 1.94 \\
\hline
\end{tabular}

${ }^{\text {a}}$ Spring, March to May; summer, June to August; autumn, September to November; winter, December to February; $n$, number of samples; BDL, below detection limit.

Packard, HP6890) equipped with a split/splitless injector, fused silica capillary column $(\mathrm{HP}-5,25 \mathrm{~m} \times 0.2 \mathrm{~mm}$ id $\times$ $0.5 \mu \mathrm{m}$ film thickness) and flame ionization detector. The oven temperature was held at $50^{\circ} \mathrm{C}$ for 2 min, ramped at $30^{\circ} \mathrm{C} / \mathrm{min}$ to $120^{\circ} \mathrm{C}$, then at $6^{\circ} \mathrm{C} / \mathrm{min}$ to $310^{\circ} \mathrm{C}$, and held for 10 min. Peak identification was carried out by comparison of the GC retention times with those of authentic standards (derivatives of $\mathrm{C}_{2}-\mathrm{C}_{11}$ diacids, glyoxylic acid, 4-oxobutanoic acid, pyruvic acid, glyoxal and methylglyoxal). Identification of esters and acetals was also confirmed by mass spectral analysis using a $\mathrm{GC} / \mathrm{mass}$ spectrometry system (Thermoquest, Trace MS) with similar GC column conditions. The quantification of the compounds was performed in comparison to the GC response factors with those of authentic standards. The GC peak areas were calculated with Shimadzu C-R7A Plus integrator.

[13] We spiked free diacids on precombusted quartz fiber filters in order to test the recovery. They were extracted and analyzed like the real samples. The recoveries ranged between $80 \%$ and $85 \%$ for oxalic acid and more than $90 \%$ for malonic, glutaric, succinic, and adipic acids. Kawamura and Yasui [2005] reported that the recoveries were $88 \%$, $72 \%$, and $47 \%$ for glyoxylic acid, pyruvic acid, and methylglyoxal, respectively, following the same analytical procedure in our laboratory. Repeated analyses of the filter sample showed that the analytical error of this method was less than $10 \%$ for major species reported in this study. Field blanks showed small peaks of oxalic, succinic, adipic, and phthalic acids and methylglyoxal. However, their levels were very low $(0.1 \%-3 \%)$ compared to those of the real samples. The reported concentrations for the samples are corrected for the field blanks, but not for recoveries.

[14] The concentrations of OC and EC were measured using an OC/EC analyzer (Sunset Laboratory Inc., Portland, $\mathrm{OR})$. The WSOC was measured with a carbon analyzer (Shimadzu, TOC-5000), whereas water-soluble inorganic ions were measured using a Metrohm 761 ion chromatography system (Metrohm, Herisau, Switzerland). The detailed analytical methods for the measurements of OC, EC, 


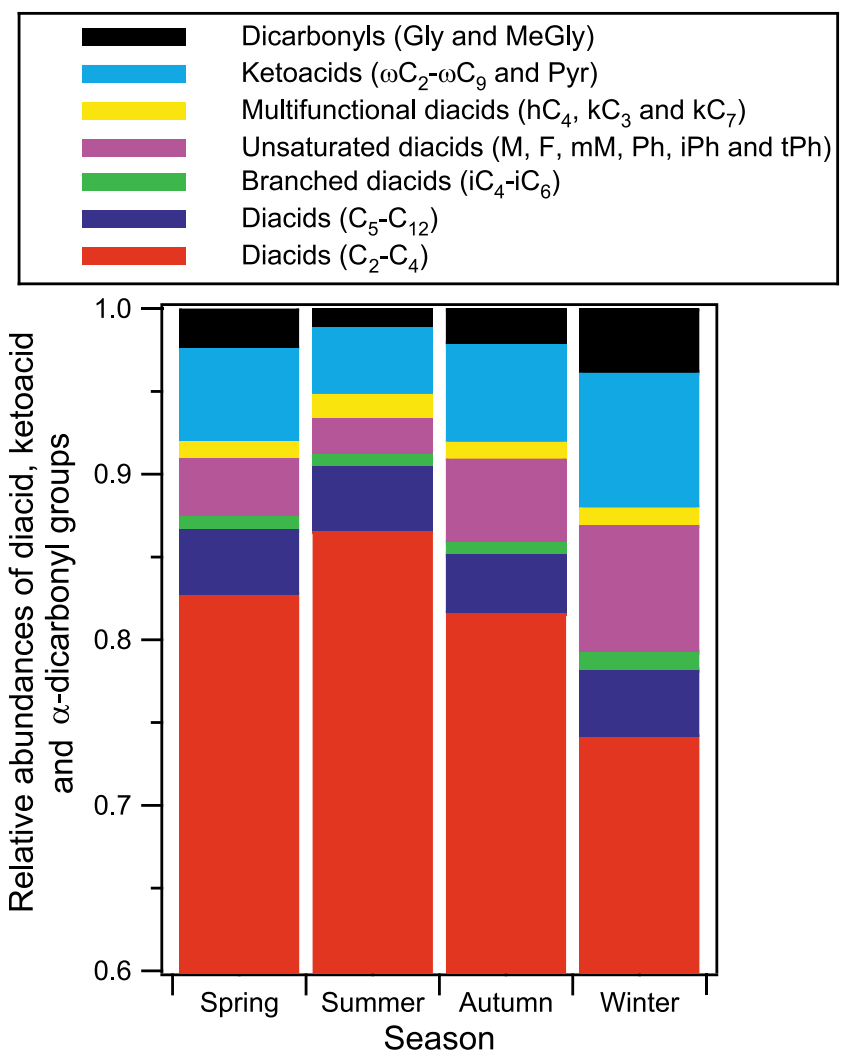

Figure 3. Seasonal difference in the relative abundances of diacids, ketoacids, and $\alpha$-dicarbonyls in total diacids and related compounds. The $y$ axis is scaled from $60 \%$ because straight chain diacids $\left(\mathrm{C}_{2}-\mathrm{C}_{4}\right)$ in each season account for $>60 \%$ and hence the relative abundances of other organics can be visualized.
WSOC, and water-soluble inorganic ions are described by Kundu et al. [2010b].

\section{Results and Discussion}

\subsection{Molecular Composition of Diacids, Ketoacids, and $\alpha$-Dicarbonyls}

[15] Straight and branched chain aliphatic diacids, diacids with additional functional groups, unsaturated aliphatic diacids, aromatic diacids, ketoacids, and $\alpha$-dicarbonyls were detected in this study. Table 1 presents their concentration ranges and average concentrations for four seasons together with abbreviations of the compound names. Figure 2 shows seasonally averaged molecular distributions of diacids and related compounds. Although large variations were observed among seasons, oxalic acid $\left(\mathrm{C}_{2}\right)$ was found to be the most abundant species followed by malonic acid $\left(\mathrm{C}_{3}\right)$ in all seasons. Concentrations (20-1290 $\mathrm{ng} \mathrm{m}^{-3}$, average $560 \mathrm{ng} \mathrm{m}^{-3}$ ) of oxalic acid $\left(\mathrm{C}_{2}\right)$ and its relative abundances $(64 \%-81 \%$, average $71 \%$ ) to total diacids and related compounds showed a maximum in summer and a minimum in winter. Table 2 shows relative abundances of diacids and related compounds in the total organic species detected. The relative abundances of oxalic acid $\left(\mathrm{C}_{2}\right)$ in summer are higher than those in other seasons (Table 2), pointing out an enhanced photochemical production of oxalic acid $\left(\mathrm{C}_{2}\right)$ in summer [Kawamura and Ikushima, 1993]. The dominant presence of oxalic acid $\left(\mathrm{C}_{2}\right)$ has been reported for many aerosol samples from urban [Kawamura and Kaplan, 1987; Kawamura and Ikushima, 1993; Ho et al., 2007; Miyazaki et al., 2007] and remote marine sites [Kawamura and Sakaguchi, 1999; Kerminen et al., 2000; Mochida et al., 2003a, 2003b].

[16] The third most abundant species is succinic acid $\left(\mathrm{C}_{4}\right)$ followed by glyoxylic acid $\left(\omega \mathrm{C}_{2}\right)$, glutaric acid $\left(\mathrm{C}_{5}\right)$, methylglyoxal (MeGly), phthalic acid $(\mathrm{Ph})$, and adipic acid $\left(\mathrm{C}_{6}\right)$ in warmer seasons (spring and summer; Figure 2).

Table 3. Comparison Between the Concentrations of Diacids and Related Compounds at the Gosan Site and Its Surrounding Locations

\begin{tabular}{|c|c|c|c|c|c|c|c|c|c|c|}
\hline \multirow[b]{2}{*}{ Location } & \multirow[b]{2}{*}{ Type } & \multirow[b]{2}{*}{ Period } & \multirow[b]{2}{*}{ Size } & \multirow[b]{2}{*}{ Reference } & \multicolumn{2}{|c|}{ Total Diacids $^{\mathrm{a}}$} & \multicolumn{2}{|c|}{ Total Ketoacids $^{\mathrm{a}}$} & \multicolumn{2}{|c|}{$\begin{array}{c}\text { Total } \\
\alpha \text {-Dicarbonyls } \\
\end{array}$} \\
\hline & & & & & $\begin{array}{l}\text { Range } \\
\left(\mathrm{ng} \mathrm{m}^{-3}\right)\end{array}$ & $\begin{array}{l}\text { Average } \\
\left(\mathrm{ng} \mathrm{m}^{-3}\right)\end{array}$ & $\begin{array}{l}\text { Range } \\
\left(\mathrm{ng} \mathrm{m}^{-3}\right)\end{array}$ & $\begin{array}{l}\text { Average } \\
\left(\mathrm{ng} \mathrm{m}^{-3}\right)\end{array}$ & $\begin{array}{l}\text { Range } \\
\left(\mathrm{ng} \mathrm{m}^{-3}\right)\end{array}$ & $\begin{array}{l}\text { Average } \\
\left(\mathrm{ng} \mathrm{m}^{-3}\right)\end{array}$ \\
\hline $\begin{array}{l}\text { Gosan, Jeju Island, } \\
\text { South Korea }\end{array}$ & Remote/marine & Apr 2001 to Mar 2002 & TSP & Kawamura et al. [2004] & $130-2070$ & 660 & $2-172$ & 53 & $0.1-84$ & 12 \\
\hline East China Sea & Open ocean & 15 Mar to 19 Apr 2001 & TSP & Mochida et al. [2003b] & $410-1500$ & 850 & - & - & - & - \\
\hline Japan Sea & Open ocean & 16 Mar to 19 Apr 2001 & TSP & Mochida et al. [2003b] & $480-2100$ & 1200 & - & - & - & - \\
\hline $\begin{array}{l}\text { Chichi-jima, } \\
\text { Japan }\end{array}$ & Remote/marine & Apr 1990 to Nov 1993 & TSP & Mochida et al. [2003a] & $6-550$ & 139 & - & - & - & - \\
\hline Tokyo & Urban & Apr 1988 to Feb 1989 & TSP & $\begin{array}{l}\text { Kawamura and } \\
\text { Ikushima [1993] }\end{array}$ & $90-1370$ & 480 & - & - & - & - \\
\hline Tokyo & Urban & 2-3 Jun 1989 & TSP & $\begin{array}{l}\text { Kawamura and } \\
\text { Yasui }[2005]\end{array}$ & $164-1804$ & 506 & $22-285$ & 96.7 & $8-116$ & 37 \\
\hline $\begin{array}{l}\text { Chinese } \\
\text { megacities }\end{array}$ & Urban & $\begin{array}{c}\text { 21-22 Jul } 1989 \\
\text { 20-21 Nov } 1989 \\
\text { 13-14 Jan } 2003\end{array}$ & $\mathrm{PM}_{2.5}$ & Ho et al. [2007] & $319-1940$ & 904 & $5-118$ & 45 & $\mathrm{BDL}^{\mathrm{b}}-64$ & 12 \\
\hline This study & Remote/marine & $\begin{array}{c}\text { Jun and Jul } 2003 \\
\text { Apr } 2003 \text { to Apr } 2004\end{array}$ & TSP & & $142-1875$ & 636 & $8-170$ & 41 & $2-108$ & 15 \\
\hline
\end{tabular}

${ }^{\mathrm{a}}$ Total diacids, ketoacids, and dicarbonyls include the chemical species listed in Table 1. See also cited references.

${ }^{\mathrm{b}} \mathrm{BDL}$, below detection limit. 
(a) Spring
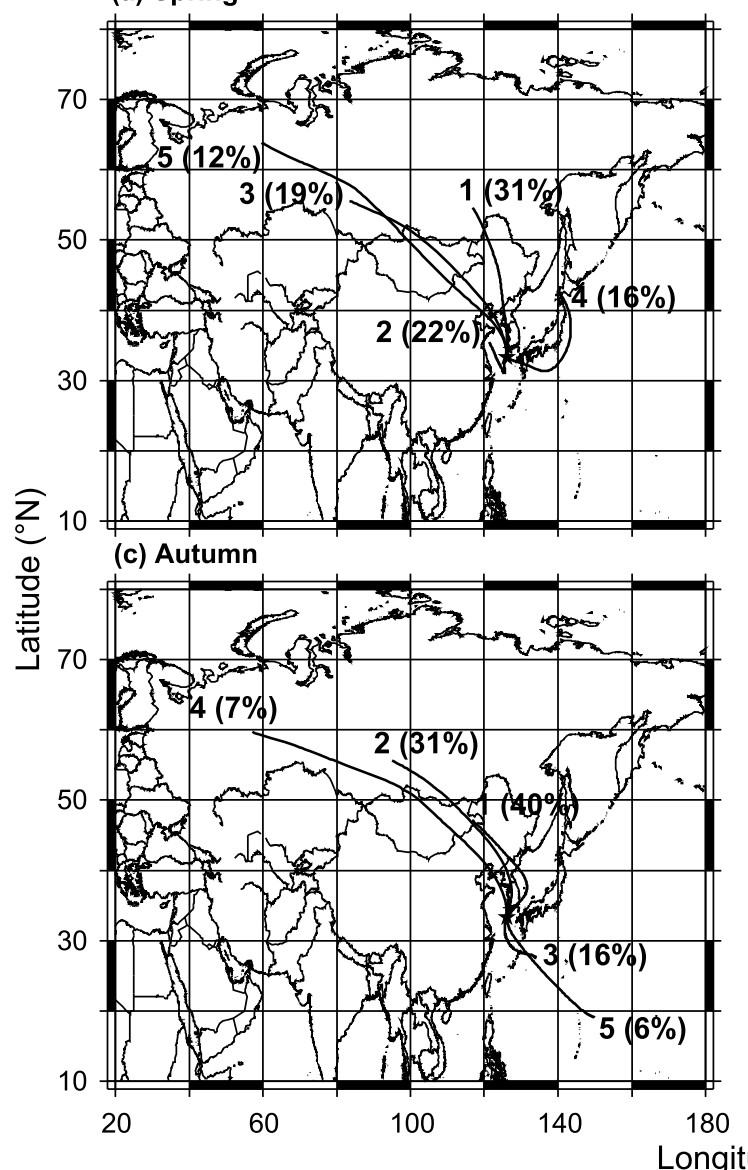

(b) Summer

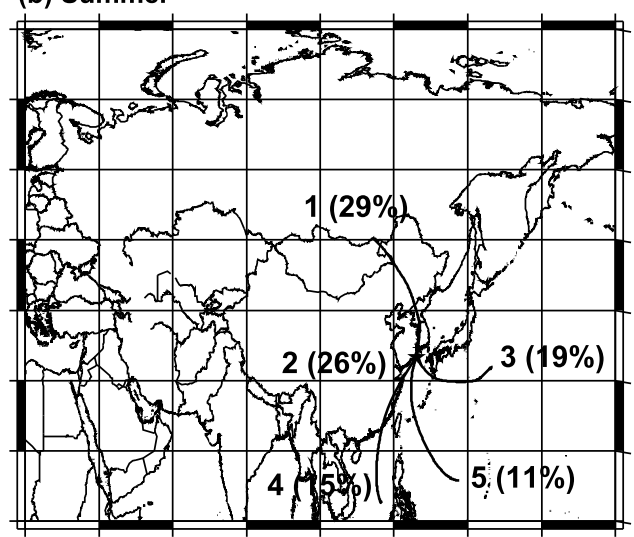

(d) Winter

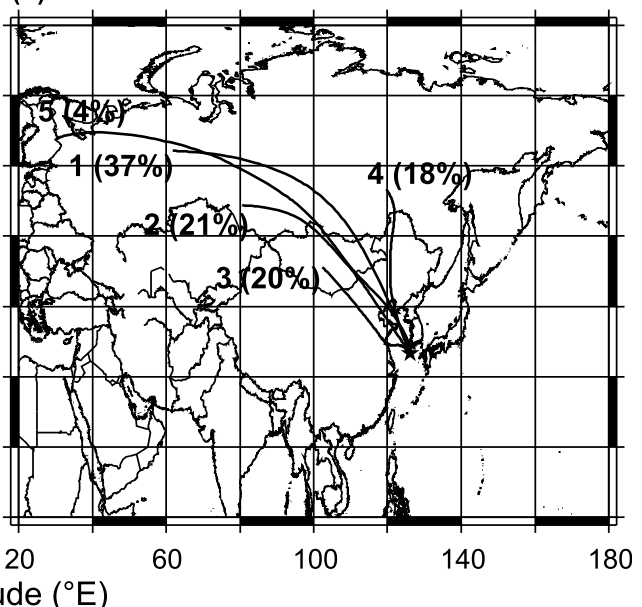

Figure 4. Mean horizontal plots of air mass backward trajectories for the main trajectory clusters in (a) spring, (b) summer, (c) autumn, and (d) winter. Backward trajectories for 5 days at $500 \mathrm{~m}$ above ground level were drawn with the NOAA HYSPLIT model. The trajectories in each season were grouped into five clusters as suggested by the model. The numbers 1 to 5 indicate the name of mean clusters. Clusters are arbitrarily named according to descending order of the origin of air masses. The numbers in parentheses indicate the percentage of total air mass transport from the origins. The star indicates the location of sampling site.

Either succinic acid $\left(\mathrm{C}_{4}\right)$ or glyoxylic acid $\left(\omega \mathrm{C}_{2}\right)$ is the third most abundant species in colder seasons (autumn and winter) followed by phthalic acid ( $\mathrm{Ph})$, methylglyoxal (MeGly), glutaric acid $\left(\mathrm{C}_{5}\right)$, and adipic acid $\left(\mathrm{C}_{6}\right)$ (Figure 2$)$. Azelaic acid $\left(\mathrm{C}_{9}\right)$ was the most abundant in the range of $\mathrm{C}_{7}-\mathrm{C}_{12}$ diacids in all seasons. The highest relative abundances for straight chain $\left(\mathrm{C}_{2}-\mathrm{C}_{12}\right)$, and multifunctional diacids were found in summer, whereas the highest relative abundances for branched and unsaturated diacids, ketoacids, and dicarbonyls were observed in winter (Figure 3).

Table 4. Contributions of Diacids, Ketoacids, and $\alpha$-Dicarbonyls to Carbonaceous Fractions (Organic Carbon and Water-Soluble Organic Carbon) of Aerosols at Gosan, Jeju Island, South Korea

\begin{tabular}{|c|c|c|c|c|c|c|c|c|}
\hline \multirow[b]{2}{*}{$\begin{array}{l}\text { Abundance in } \\
\text { Bulk Carbon }\end{array}$} & \multicolumn{2}{|c|}{ Spring } & \multicolumn{2}{|c|}{ Summer } & \multicolumn{2}{|c|}{ Autumn } & \multicolumn{2}{|c|}{ Winter } \\
\hline & $\begin{array}{l}\text { Range } \\
(\%)\end{array}$ & $\begin{array}{c}\text { Average } \\
(\%)\end{array}$ & $\begin{array}{l}\text { Range } \\
(\%)\end{array}$ & $\begin{array}{c}\text { Average } \\
(\%)\end{array}$ & $\begin{array}{l}\text { Range } \\
(\%)\end{array}$ & $\begin{array}{c}\text { Average } \\
(\%)\end{array}$ & $\begin{array}{c}\text { Range } \\
(\%)\end{array}$ & $\begin{array}{c}\text { Average } \\
(\%)\end{array}$ \\
\hline \multicolumn{9}{|l|}{ Organic carbon } \\
\hline Total diacids & $2-8.8$ & 5.3 & $3.4-14.8$ & 8.4 & $4.4-17.1$ & 7.6 & $2.8-7.7$ & 5.2 \\
\hline Total ketoacids & $0.2-0.8$ & 0.4 & $0.2-0.7$ & 0.4 & $0.3-1.2$ & 0.6 & $0.2-0.8$ & 0.5 \\
\hline Total $\alpha$-dicarbonyls & $0.04-0.5$ & 0.2 & $0.06-0.3$ & 0.2 & $0.13-0.5$ & 0.3 & $0.2-0.7$ & 0.3 \\
\hline \multicolumn{9}{|c|}{ Water-soluble organic carbon } \\
\hline Total diacids & $4.2-14.0$ & 9.6 & $6.8-25.2$ & 15.3 & $7.7-26.4$ & 14.6 & $4.8-12.7$ & 8.5 \\
\hline Total ketoacids & $0.3-1.2$ & 0.7 & $0.4-1.1$ & 0.7 & $0.6-2.1$ & 1.0 & $0.4-1.2$ & 0.8 \\
\hline Total $\alpha$-dicarbonyls & $0.08-0.9$ & 0.4 & $0.1-0.5$ & 0.3 & $0.3-1.1$ & 0.5 & $0.3-1.0$ & 0.5 \\
\hline
\end{tabular}




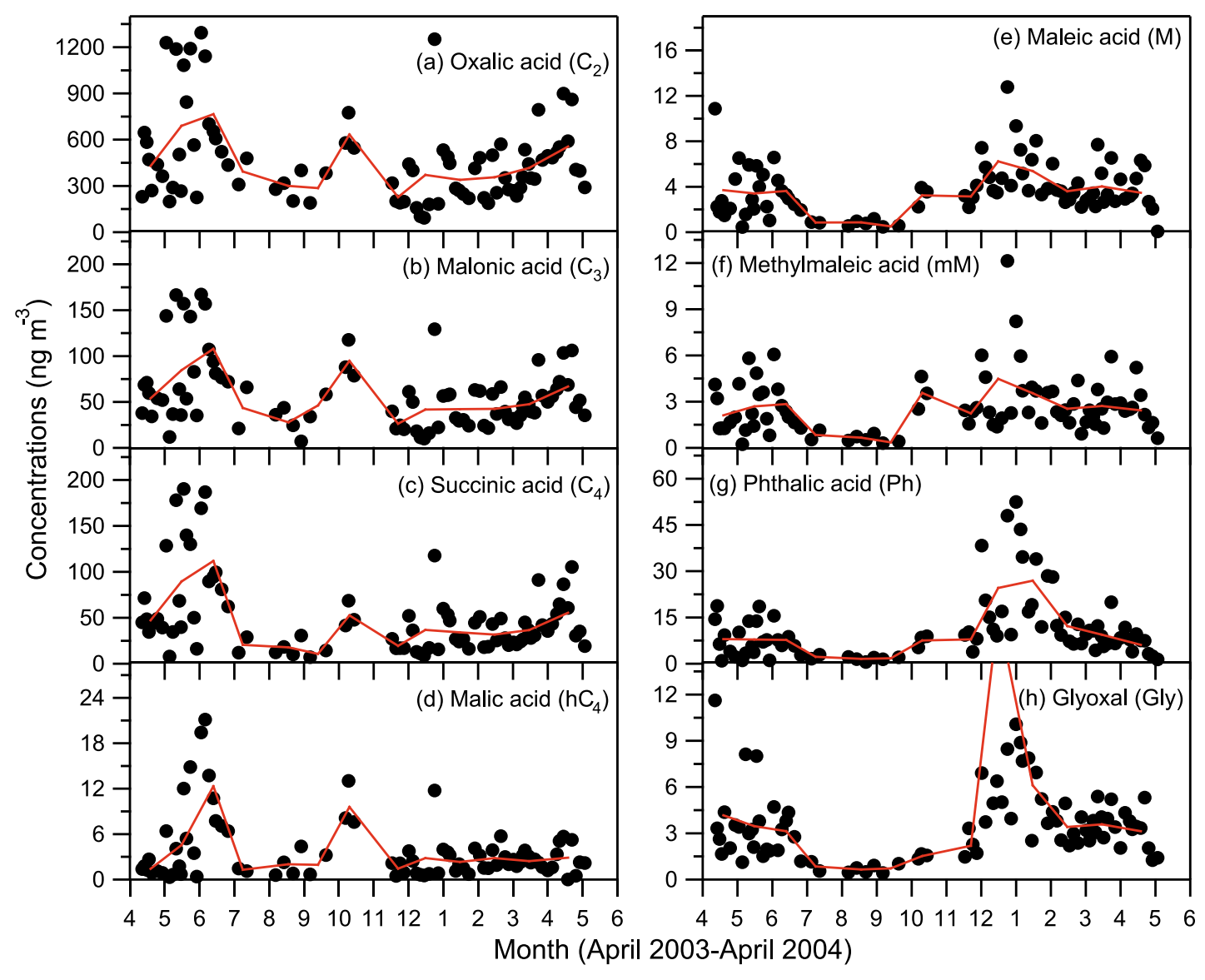

Figure 5. Seasonal variations of (a) oxalic acid $\left(C_{2}\right)$, (b) malonic acid $\left(C_{3}\right)$, (c) succinic acid $\left(C_{4}\right)$, (d) malic acid $\left(\mathrm{hC}_{4}\right)$, (e) maleic acid (M), (f) methylmaleic acid (mM), (g) phthalic acid (Ph), and (h) glyoxal (Gly). The red lines indicate monthly average data points.

[17] The average concentrations of total diacids are $735 \mathrm{ng} \mathrm{m}^{-3}$ in spring, $784 \mathrm{ng} \mathrm{m}^{-3}$ in summer, $525 \mathrm{ng} \mathrm{m}^{-3}$ in autumn, and $500 \mathrm{ng} \mathrm{m}^{-3}$ in winter (Table 1). The concentrations of total diacids at the Gosan site and its surrounding areas are compared in Table 3. Gosan data of this study is similar to those reported at Gosan for aerosol samples collected between April 2001 and March 2002 [Kawamura et al., 2004]. Similar concentrations were reported over the East China Sea for aerosols collected by a ship during ACE-Asia campaign, whereas much higher concentrations were reported over the Japan Sea [Mochida et al., 2003b]. Total diacid concentrations in aerosols over Chichi-jima Island in the western North Pacific, $\sim 2000 \mathrm{~km}$ away from East Asia, are several times lower than those observed at our Gosan site, suggesting that the Gosan site is strongly influenced by the continental outflow from China, Korea, and Japan due to its vicinity. Total diacid concentrations at our site are higher than those in urban Tokyo, but similar to those reported in 14 Chinese megacities [Ho et al., 2007]. This comparison demonstrates that the outflows from China to Gosan are an important transport pathway.

[18] Air mass back trajectories are given in Figure 4. It is worthy to note that the highest average concentration of total diacids was observed in summer (Table 1), although $45 \%$ of air masses are transported from the oceans (Figure 4b). Ho et al. [2007] reported that during winter total diacids in central and southern China were higher than those in northern China, whereas during summer total diacids were higher in northern and central China than in southern China. Figure $4 \mathrm{~b}$ shows that $55 \%$ of air masses in summer are transported over northern and central China. This air mass transport pattern along with the higher concentrations of total diacids over northern and central China in summer [Ho et al., 2007] may explain the maximum average concentration of total diacids at Gosan in summer.

[19] Average total ketoacid concentrations are $46 \mathrm{ng} \mathrm{m}^{-3}$ in spring, $36 \mathrm{ng} \mathrm{m}^{-3}$ in summer, $34 \mathrm{ng} \mathrm{m}^{-3}$ in autumn, and $47 \mathrm{ng}$ $\mathrm{m}^{-3}$ in winter. Total $\alpha$-dicarbonyls concentrations are, on average, $18 \mathrm{ng} \mathrm{m}^{-3}$ in spring, $9 \mathrm{ng} \mathrm{m}^{-3}$ in summer, $11 \mathrm{ng} \mathrm{m}^{-3}$ in autumn, and $23 \mathrm{ng} \mathrm{m}^{-3}$ in winter. These concentrations are compared with those at the surrounding locations of the Gosan site (Table 3). The values are similar to those reported at our sampling site for aerosol samples collected between April 2001 and March 2002 [Kawamura et al., 2004]. Concentrations of ketoacids and $\alpha$-dicarbonyls reported in 14 Chinese megacities [Ho et al., 2007] are similar to our results at the Gosan site, further suggesting an important outflow and chemical evolution of organics in the gas and aerosol phases during a long-range transport (average 12 days) from China to the Gosan site.

[20] The secondary organic carbon (SOC) can provide information about the photochemical aging of organic aerosols. The SOC was estimated using the EC tracer method [Lim and Turpin, 2002] and the representative ratio 


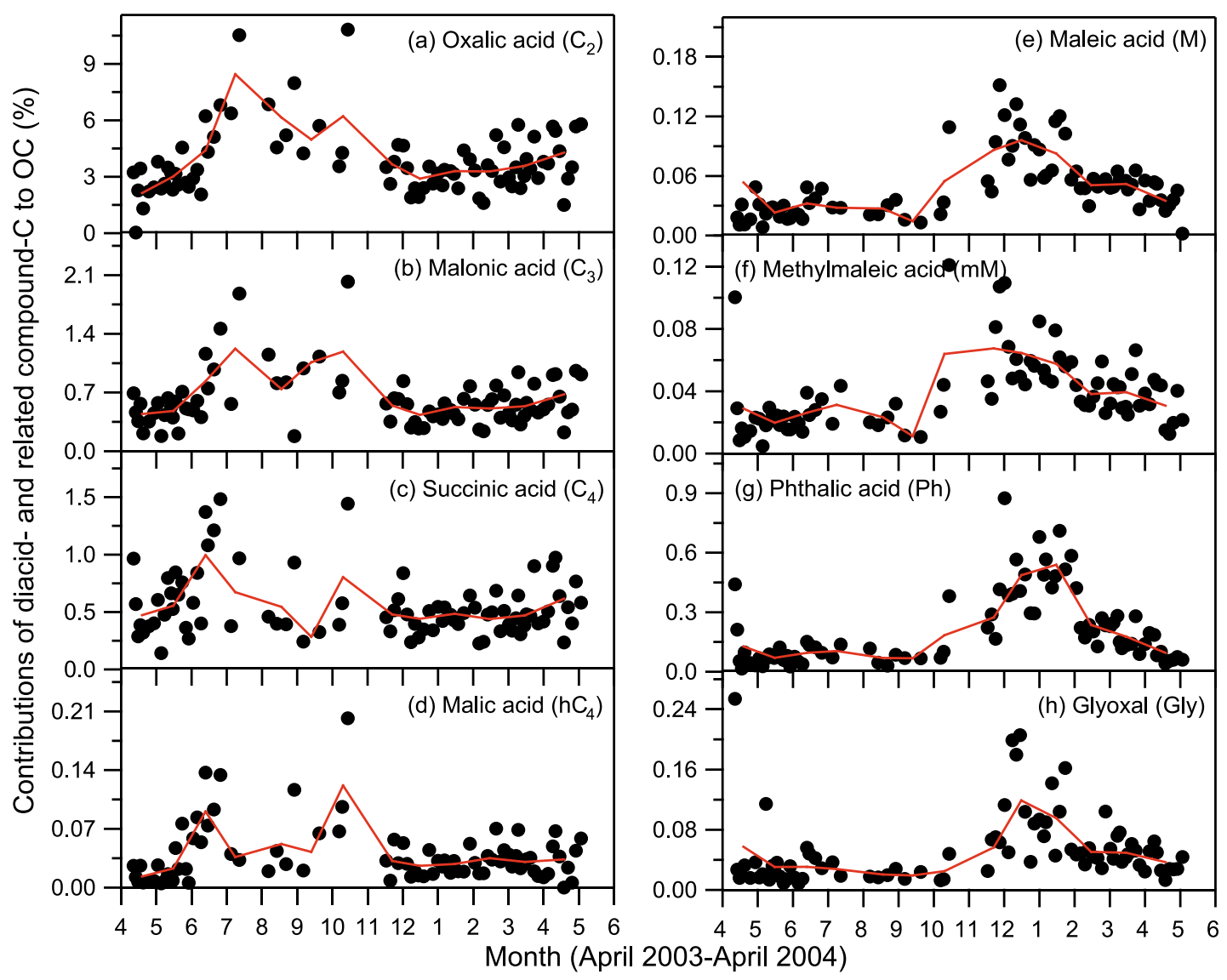

Figure 6. Seasonal variations in the carbon component of (a) oxalic acid $\left(\mathrm{C}_{2}\right),(\mathrm{b})$ malonic acid $\left(\mathrm{C}_{3}\right),(\mathrm{c})$ succinic acid $\left(\mathrm{C}_{4}\right)$, (d) malic acid $\left(\mathrm{hC}_{4}\right)$, (e) maleic acid (M), (f) methylmaleic acid (mM), (g) phthalic acid $(\mathrm{Ph})$, and (h) glyoxal (Gly) to organic carbon. The red lines indicate monthly average data points.

$(\mathrm{OC} / \mathrm{EC})_{\text {primary }}=1.99$, which was derived from OC and EC data of aerosol samples collected from northern China $[\mathrm{Ho}$ et al., 2007]. It is reasonable to use this value because major fraction of air masses at the Gosan site are transported from northern China (Figure 4) and the direct application of the EC tracer method should be erroneous under conditions of extensive chemical processes in the Gosan aerosols [Strader et al., 1999]. We found that the carbon content of total diacids correlate well with the SOC $\left(\mathrm{r}^{2}=0.60, p<\right.$ $0.0001, n=84)$. Additionally, the contributions of diacids, ketoacids, and $\alpha$-dicarbonyls to OC and WSOC are several times higher than those reported in 14 Chinese megacities [Ho et al., 2007] (Table 4). These results suggest an important secondary production of diacids and related compounds due to the oxidation of volatile and semivolatile organic precursors and a photochemical aging of organic aerosols during a long-range transport from East Asia.

\subsection{Seasonal Variations of Diacids, Ketoacids, and $\alpha$-Dicarbonyls}

[21] Individual species of diacids and related compounds showed two different seasonal trends. The first group of compounds, including straight chain and multifunctional diacids (such as oxalic $\left(\mathrm{C}_{2}\right)$, malonic $\left(\mathrm{C}_{3}\right)$, succinic $\left(\mathrm{C}_{4}\right)$, and malic $\left(\mathrm{hC}_{4}\right)$ acids), showed maximum concentrations in late spring to early summer (Figures $5 \mathrm{a}-5 \mathrm{~d}$ ). In contrast, the second group of compounds, including unsaturated diacids (such as maleic $(\mathrm{M})$, methylmaleic $(\mathrm{mM})$, and phthalic $(\mathrm{Ph})$ acids) and $\alpha$-dicarbonyls (such as glyoxal (Gly)), showed maxima in winter (Figures 5e-5h). The different seasonal variations between the first and second groups suggest a difference in the sources or atmospheric processing. If the physical parameters such as lower mixing heights, surface inversion layers, and infrequent precipitations were the causes for the maximum concentrations, both the first and second groups showed a same trend. Thus, the different seasonal trends should be caused by a difference in the emission of their precursors or photochemical processing.

[22] The organic precursors that produce the compounds showing maximum concentrations in winter are mainly aromatics in nature although glyoxal (Gly), to some extent, can be produced due to the oxidation of some nonaromatic organics such as ethene, ethyne, and isoprene [Warneck, 2003; Ervens et al., 2004; Ieda et al., 2006]. The temperature ranges between $-14^{\circ} \mathrm{C}$ and $5^{\circ} \mathrm{C}$ during winter in northern China [Ho et al., 2007], from which almost all of the air masses are transported over our sampling site (Figure 4d). Coals/biomasses, in which combustion efficiency is very low, are commonly used in China for heating and cooking [Wang et al., 2006]. Total residential energy consumption in Beijing, located in northern China, in colder seasons (autumn and winter) is 5.4 tons of coal equivalent in 2006, 


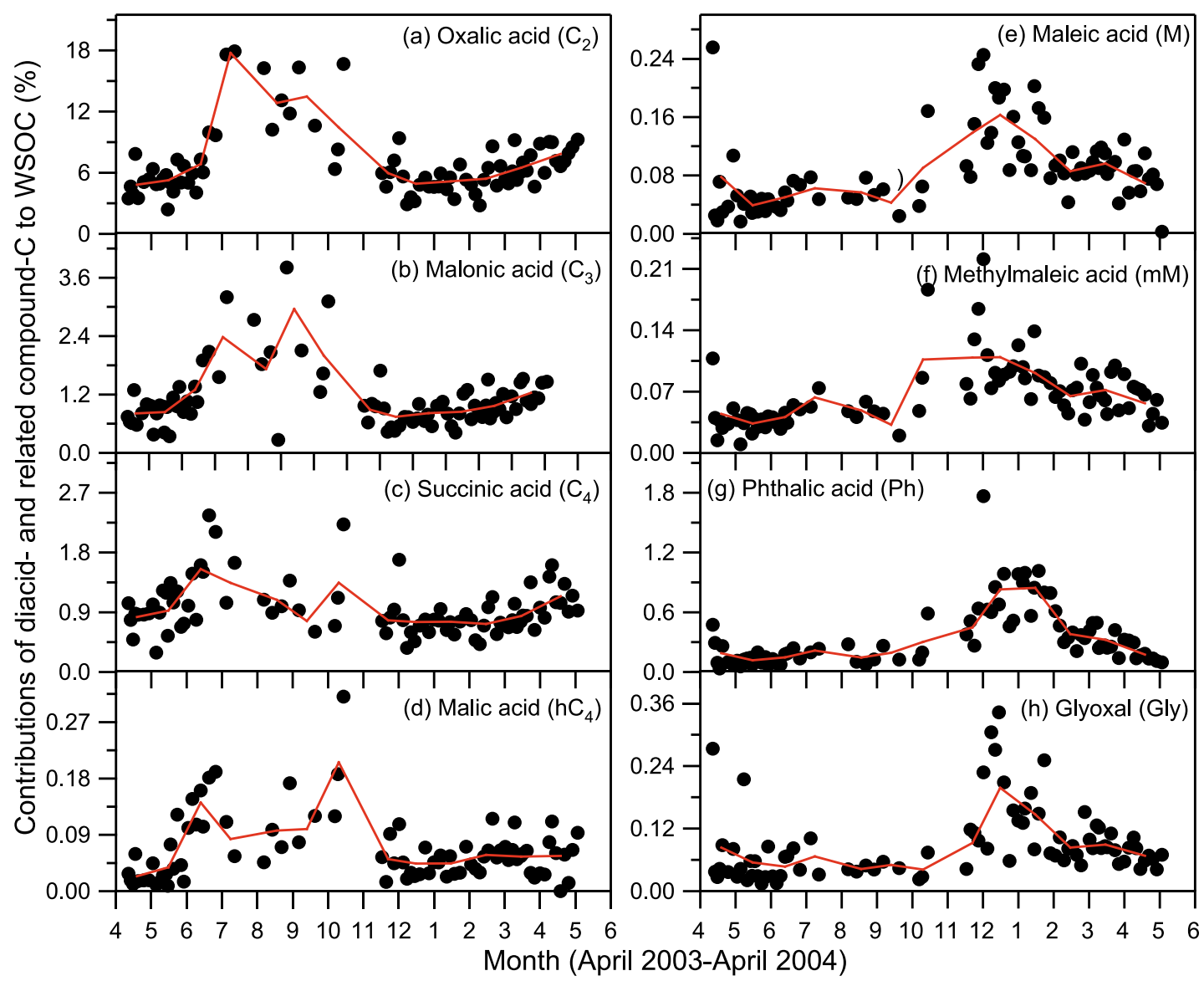

Figure 7. Seasonal variations in the carbon component of (a) oxalic acid $\left(\mathrm{C}_{2}\right),(\mathrm{b})$ malonic acid $\left(\mathrm{C}_{3}\right),(\mathrm{c})$ succinic acid $\left(\mathrm{C}_{4}\right)$, (d) malic acid $\left(\mathrm{hC}_{4}\right)$, (e) maleic acid (M), (f) methylmaleic acid (mM), (g) phthalic acid $(\mathrm{Ph})$, and $(\mathrm{h})$ glyoxal (Gly) to water-soluble organic carbon. The red lines indicate monthly average data points.

which is $54 \%$ higher than that in warmer seasons (spring and summer; http://www.bjstats.gov.cn). Coal/biomass combustion emits huge amounts of aromatics (e.g., the emission of polycyclic aromatic hydrocarbons in Chinese megacities is more than seven times higher in winter than in summer) [Wang et al., 2006].

[23] Carbon contents of individual diacids and related compounds were normalized by OC and WSOC to examine the seasonal variations. Figures 6 and 7 present seasonal variations of individual compounds normalized by $\mathrm{OC}$ and WSOC, respectively. Higher values were found in summer for straight chain and multifunctional diacids (Figures $6 \mathrm{a}-6 \mathrm{~d}$ and $7 \mathrm{a}-7 \mathrm{~d})$, being consistent with an enhanced secondary production due to higher oxidant concentrations and warmer temperature. In contrast, higher values were observed in winter for unsaturated acids and $\alpha$-dicarbonyls (Figures 6e$6 \mathrm{~h}$ and $7 \mathrm{e}-7 \mathrm{~h}$ ), suggesting an enhanced emission potentially from coal/biomass combustion. Higher contributions of total diacids to OC were observed in summer, whereas those of total ketoacids and $\alpha$-dicarbonyls showed higher values in autumn and winter (Table 4). Similar seasonal variations were observed for the contributions of total diacids, ketoacids, and $\alpha$-dicarbonyls to WSOC (Table 4).

\subsection{Seasonal Variations in the Concentration Ratios of Diacids and Related Compounds}

[24] Figure 8 shows the seasonal variations of $\mathrm{C}_{2} / \omega \mathrm{C}_{2}$, $\mathrm{C}_{2} / \mathrm{Pyr}, \mathrm{C}_{2} / \mathrm{Gly}, \mathrm{C}_{3} / \mathrm{C}_{4}, \mathrm{~F} / \mathrm{M}$, and $\mathrm{hC}_{4} / \mathrm{C}_{4}$ ratios. These organic species (except oxalic acid $\left(\mathrm{C}_{2}\right)$ ) have been proposed to be associated in atmospheric chain reactions to produce oxalic acid [Kawamura et al., 1996]. $\mathrm{C}_{2} / \omega \mathrm{C}_{2}, \mathrm{C}_{2} / \mathrm{Pyr}$, and $\mathrm{C}_{2} /$ Gly ratios have shown higher values in summer and lower values in winter (Figures 8a-8c). This trend is a possible indication of photochemical production of oxalic acid $\left(\mathrm{C}_{2}\right)$ from glyoxylic $\left(\omega \mathrm{C}_{2}\right)$ and pyruvic (Pyr) acids and glyoxal (Gly). Carlton et al. [2006] demonstrated that photochemical oxidation of pyruvic acid (Pyr) yields oxalic $\left(\mathrm{C}_{2}\right)$ and glyoxylic $\left(\omega \mathrm{C}_{2}\right)$ acids in the aerosol phase and acetic and formic acids in the gas phase. Oxalic acid $\left(\mathrm{C}_{2}\right)$ is also produced from oxidation of glyoxal via formation of glyoxylic acid as intermediate in cloud waters [Warneck, 2003].

[25] Lower $\mathrm{C}_{3} / \mathrm{C}_{4}$ ratios (ranging from 0.25 to 0.44 with an average of 0.35 [Kawamura and Kaplan, 1987]) were observed in aerosols from automobile emission. This is in contrast to those reported in atmospheric aerosols from Tokyo (0.56-2.9, average 1.6 [Kawamura and Ikushima, 1993]) and Chinese megacities (0.6-1.1, average 0.74 [Ho et al., 2007]). Thus, $\mathrm{C}_{3} / \mathrm{C}_{4}$ ratios may effectively be used 


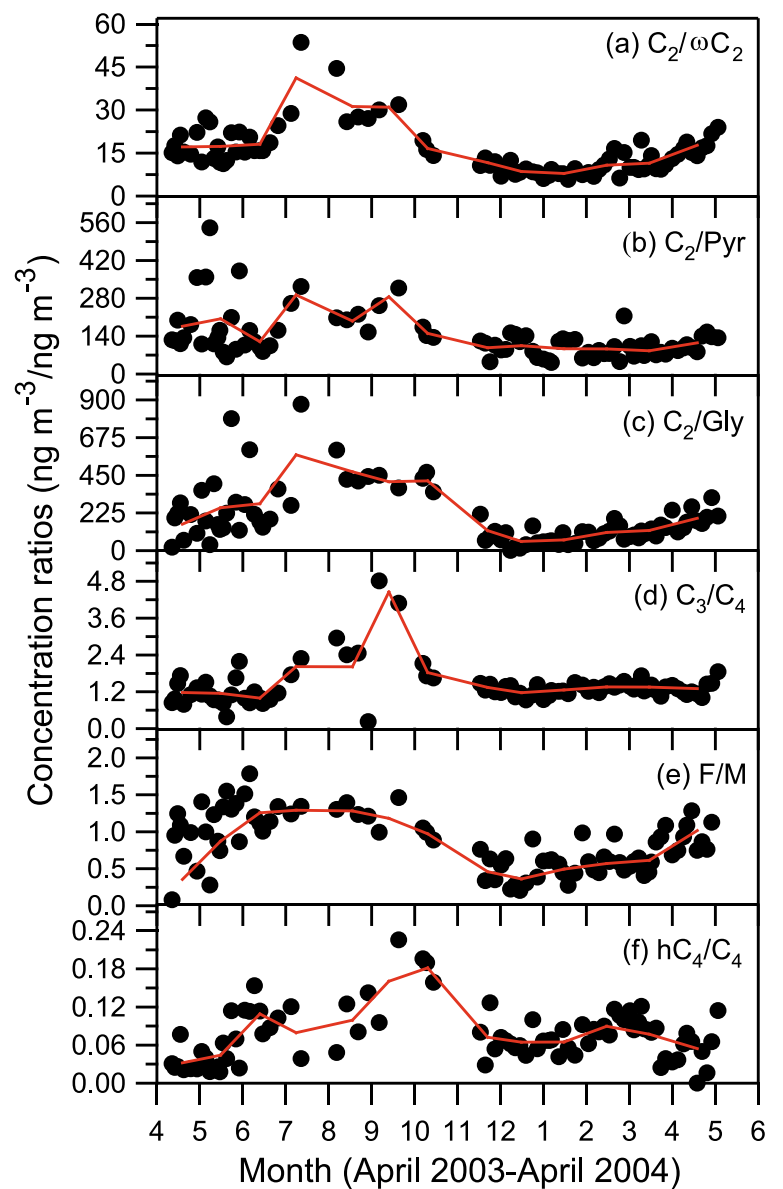

Figure 8. Seasonal variations in the ratios of (a) $\mathrm{C}_{2} / \omega \mathrm{C}_{2}$, (b) $\mathrm{C}_{2} / \mathrm{Pyr}$, (c) $\mathrm{C}_{2} / \mathrm{Gly}$, (d) $\mathrm{C}_{3} / \mathrm{C}_{4}$, (e) F/M, and (f) $\mathrm{hC}_{4} / \mathrm{C}_{4}$. The red lines indicate monthly average data points.

to distinguish the relative importance of their primary and secondary sources [Kawamura and Ikushima, 1993]. It has been proposed that succinic acid $\left(\mathrm{C}_{4}\right)$ can be degraded to malonic acid $\left(\mathrm{C}_{3}\right)$ due to the abstraction of its hydrogen by $\mathrm{OH}$ radicals and subsequent decarboxylation reactions [Kawamura and Ikushima, 1993]. Figure 8d shows higher $\mathrm{C}_{3} / \mathrm{C}_{4}$ ratios in summer. This result may suggest that a significant fraction of malonic acid $\left(\mathrm{C}_{3}\right)$ is secondarily produced in the atmosphere by photochemical degradation of succinic acid $\left(\mathrm{C}_{4}\right)$. Since the Gosan site is heavily influenced by the air mass transported from East Asia, it is interesting to compare the $\mathrm{C}_{3} / \mathrm{C}_{4}$ ratios at the Gosan site with those from different cities in East Asia (Figure 9a). The $\mathrm{C}_{3} / \mathrm{C}_{4}$ ratios in Chinese cities ranged between 0.35 and 1.69 (average 0.84) in summer, and 0.13 and 1.06 (average 0.60) in winter [Ho et al., 2007]. The mean values at Gosan were observed as 1.2 in spring, 2.6 in summer, 1.3 in autumn, and 1.3 in winter. These values are about two to three times higher than those reported in Chinese megacities. Furthermore, summer average at Gosan is 2.7 times higher than that in urban Tokyo [Kawamura and Yasui, 2005]. Therefore, it appears that malonic acid $\left(\mathrm{C}_{3}\right)$ is photochemically produced during long-range transport of air masses from East Asia to Gosan.

[26] In order to further strengthen this logic, the $\mathrm{C}_{3} / \mathrm{C}_{4}$ ratios at Gosan are compared with those at Chichi-jima
Island in the western Pacific, Japan, located 1000 to $3000 \mathrm{~km}$ away from East Asian countries, but significantly influenced by the air mass flow from East Asia. The $\mathrm{C}_{3} / \mathrm{C}_{4}$ ratios at Chichi-jima (spring, 2; summer, 3.8; autumn, 1.6; 1.2, winter [Mochida et al., 2003a]) in all the seasons (except winter) are 1.3-1.7 times higher than those at Gosan. This suggests that the production of $\mathrm{C}_{3}$ from $\mathrm{C}_{4}$ is enhanced during a longrange transport to the Pacific. Interestingly, the $\mathrm{C}_{3} / \mathrm{C}_{4}$ ratios in aerosols of both Chichi-jima and Gosan have shown maxima in summer, indicating an enhanced photochemical production in warmer weather. Although very high values of $\mathrm{C}_{3} / \mathrm{C}_{4}$ ratios (3-5) were observed in aerosols collected from a background site in South Africa [Limbeck et al., 2001], lower $\mathrm{C}_{3} / \mathrm{C}_{4}$ ratios $(0.31-1.4)$ have been found in downtown and west Los Angeles [Kawamura and Kaplan, 1987] and Philadelphia [Ray and Mcdow, 2005].

[27] The laboratory studies have shown the formation of maleic anhydride from the oxidation of aromatic hydrocarbons such as benzene and toluene [Bandow et al., 1985]. Maleic acid (M) can be isomerized to fumaric acid (F) in the presence of sunlight. This isomerization reaction should be enhanced during summer. Figure $8 \mathrm{e}$ shows the seasonal changes in F/M ratio from April 2003 to April 2004. The F/M ratios are higher during summer and lower during winter. This trend is probably related with an enhanced isomerization reaction in summer under intensified solar radiation. Kawamura and Ikushima [1993] also reported the similar seasonal variations in Tokyo aerosols. Figure $9 \mathrm{~b}$ depicts the comparison of $\mathrm{F} / \mathrm{M}$ ratios at Gosan along with those reported for aerosols over Chinese megacities, other East Asian cities, and Chichi-jima in the western Pacific. The F/M ratios in summer and winter are higher at Gosan than in East Asian cities, which is probably due to an enhanced isomerization of maleic acid (M) to fumaric acid (F) during long-range transport from East Asia. Higher F/M ratios are seen at Chichi-jima, indicating more isomerization of maleic acid (M) to fumaric acid (F) in the remote marine atmosphere during a further transport from East Asia.

[28] The seasonal variations of $\mathrm{hC}_{4} / \mathrm{C}_{4}$ ratios are shown in Figure 8f. Kawamura and Ikushima [1993] hypothesized, based on the field observation, that malic acid $\left(\mathrm{hC}_{4}\right)$ can be photochemically generated from succinic acid $\left(\mathrm{C}_{4}\right)$ via hydroxylation reaction. The $\mathrm{hC}_{4} / \mathrm{C}_{4}$ ratios have shown higher values in summer, supporting this hypothesis. The average $\mathrm{hC}_{4} / \mathrm{C}_{4}$ ratio in summer was found to be 1.4-2 times higher than in other seasons, being consistent with the observation in urban Tokyo [Kawamura and Ikushima, 1993].

[29] Both adipic $\left(\mathrm{C}_{6}\right)$ and phthalic $(\mathrm{Ph})$ acids or their precursors (e.g., cyclohexene and naphthalene) are primarily emitted from the anthropogenic sources [Kawamura and Kaplan, 1987; Schauer et al., 1999, 2001, 2002]. In contrast, azelaic acid $\left(\mathrm{C}_{9}\right)$ is produced due to the oxidation of unsaturated fatty acids emitted from the biogenic sources [Kawamura and Gagosian, 1987; Rogge et al., 1991]. Thus, these ratios $\left(\mathrm{C}_{6} / \mathrm{C}_{9}\right.$ and $\left.\mathrm{Ph} / \mathrm{C}_{9}\right)$ provide their source strength from the anthropogenic and biogenic emissions. The higher the values of these ratios, the stronger the emissions from the anthropogenic sources. $\mathrm{C}_{6} / \mathrm{C}_{9}$ ratios in Figure 10 a show the lower values in midsummer. This can be interpreted by significant influence of the oceanic air masses that contain biogenic unsaturated fatty acids such as oleic acid (a precursor of $\mathrm{C}_{9}$ diacid [Kawamura and Gagosian, 1987]) in 
a)
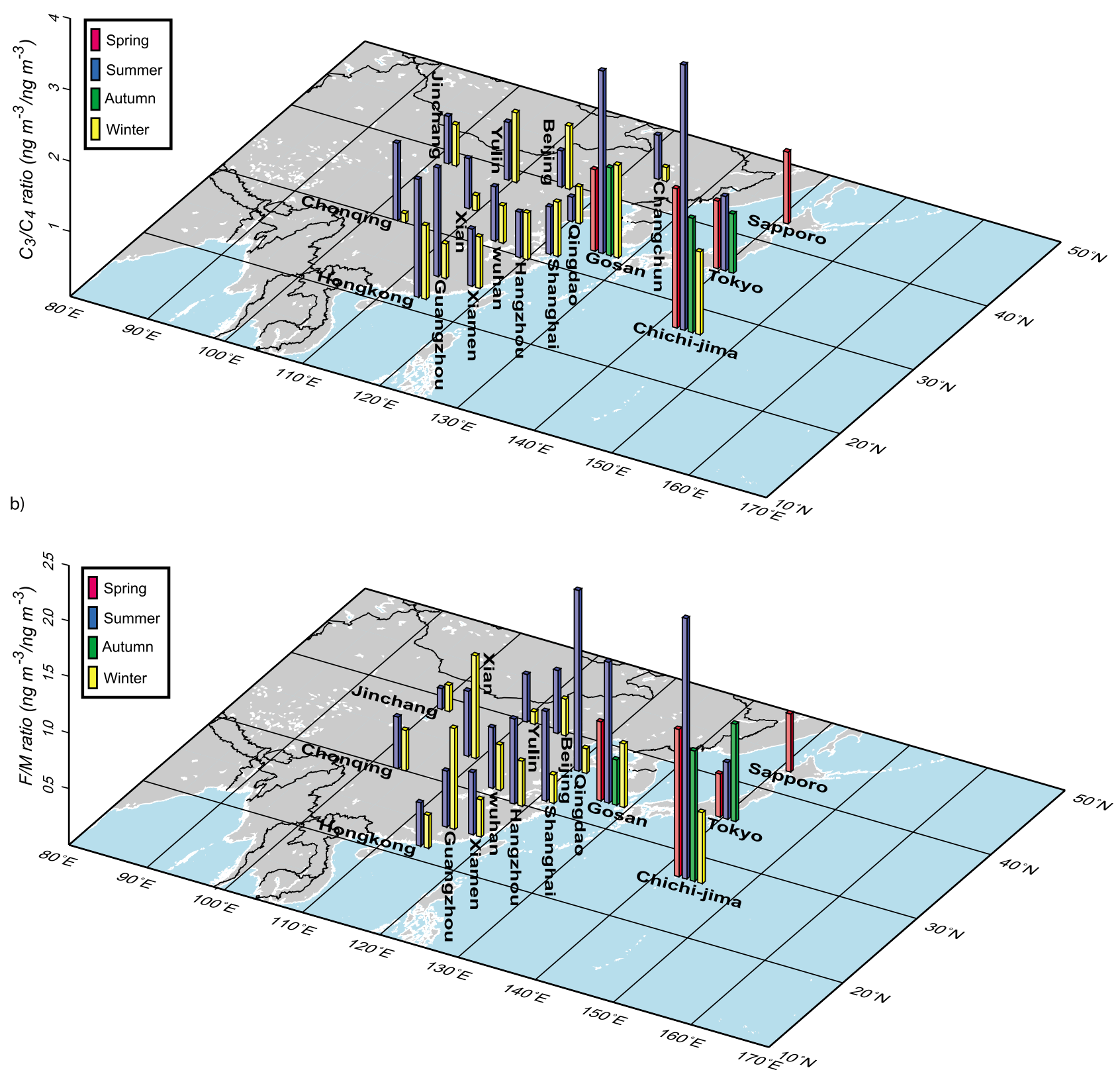

Figure 9. Depiction of (a) $\mathrm{C}_{3} / \mathrm{C}_{4}$ and (b) F/M ratios at Gosan, East Asian cities, and Chichi-jima Island in the western Pacific Ocean. The ratios in Chinese cities in summer and winter are compiled from Ho et al. [2007], those in Tokyo and Sapporo in Japan are derived from Kawamura and Yasui [2005] and S. Kundu and K. Kawamura (unpublished, 2007), and those at Chichi-jima Island are calculated from Mochida et al. [2003a]. 


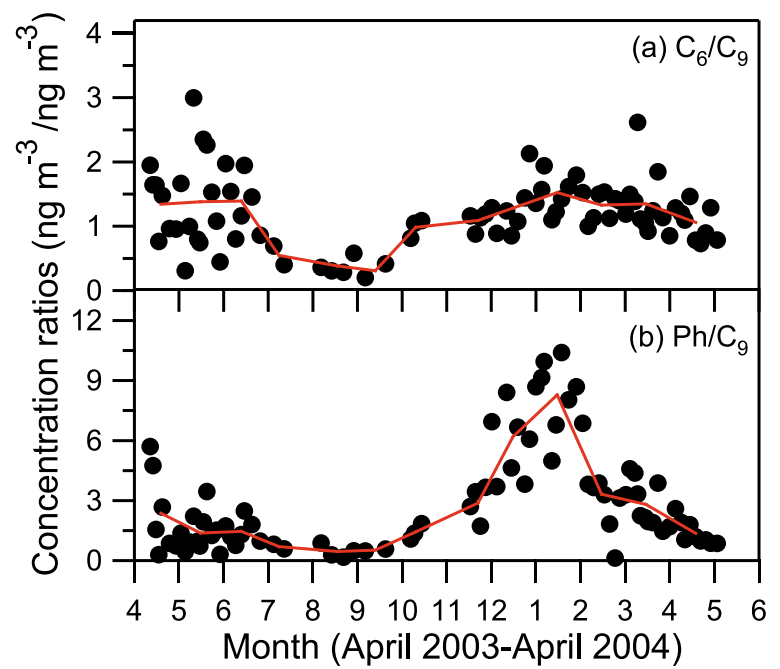

Figure 10. Seasonal variations in the ratios of (a) $\mathrm{C}_{6} / \mathrm{C}_{9}$ and (b) $\mathrm{Ph} / \mathrm{C}_{9}$. The red lines indicate monthly average data points.

Gosan aerosols during summer. Seasonal variations in $\mathrm{Ph} / \mathrm{C}_{9}$ ratios are shown in Figure 10b. They show a similar trend with $\mathrm{C}_{6} / \mathrm{C}_{9}$ ratios, but with an intensive contrast between winter and summer. The higher values in winter are caused by an enhanced transport of pollutants from East Asia, particularly in China (Figure 4d).

\subsection{Sources of Diacids, Ketoacids, and $\alpha$-Dicarbonyls}

[30] Oxalic acid $\left(\mathrm{C}_{2}\right)$ can be produced from other diacids and related compounds determined in this study due to their oxidation [Kawamura and Sakaguchi, 1999; Matsunaga et al., 1999; Warneck, 2003; Lim et al., 2005; Carlton et al., 2006; Kundu et al., 2010a]. Relative abundance of $\mathrm{C}_{2}(\%)$ in diacids and related compounds can therefore be regarded as a proxy for photochemical aging of organic aerosols. Kawamura and Yasui [2005] reported that concentrations of diacids and related compounds show inverse correlations with relative abundance of $\mathrm{C}_{2}(\%)$ in total diacids for urban Tokyo aerosols in summer. In this study, lower concentrations of diacids and related compounds in summer samples are associated with higher relative abundances of $\mathrm{C}_{2}(\%)$ in total diacids and related compounds (Figure 11). These results potentially suggest that diacids and related compounds can be broken down to oxalic acid $\left(\mathrm{C}_{2}\right)$. Diacids and related compounds can be formed from other organics in gas and aerosol phases in the early stage of photochemical processing. On the basis of the absence of similar correlations for the samples of other seasons, it can be concluded that secondary production and degradation of organic aerosols are more intensified in summer due to the stronger solar radiation, higher concentrations of oxidants, and higher ambient temperature.

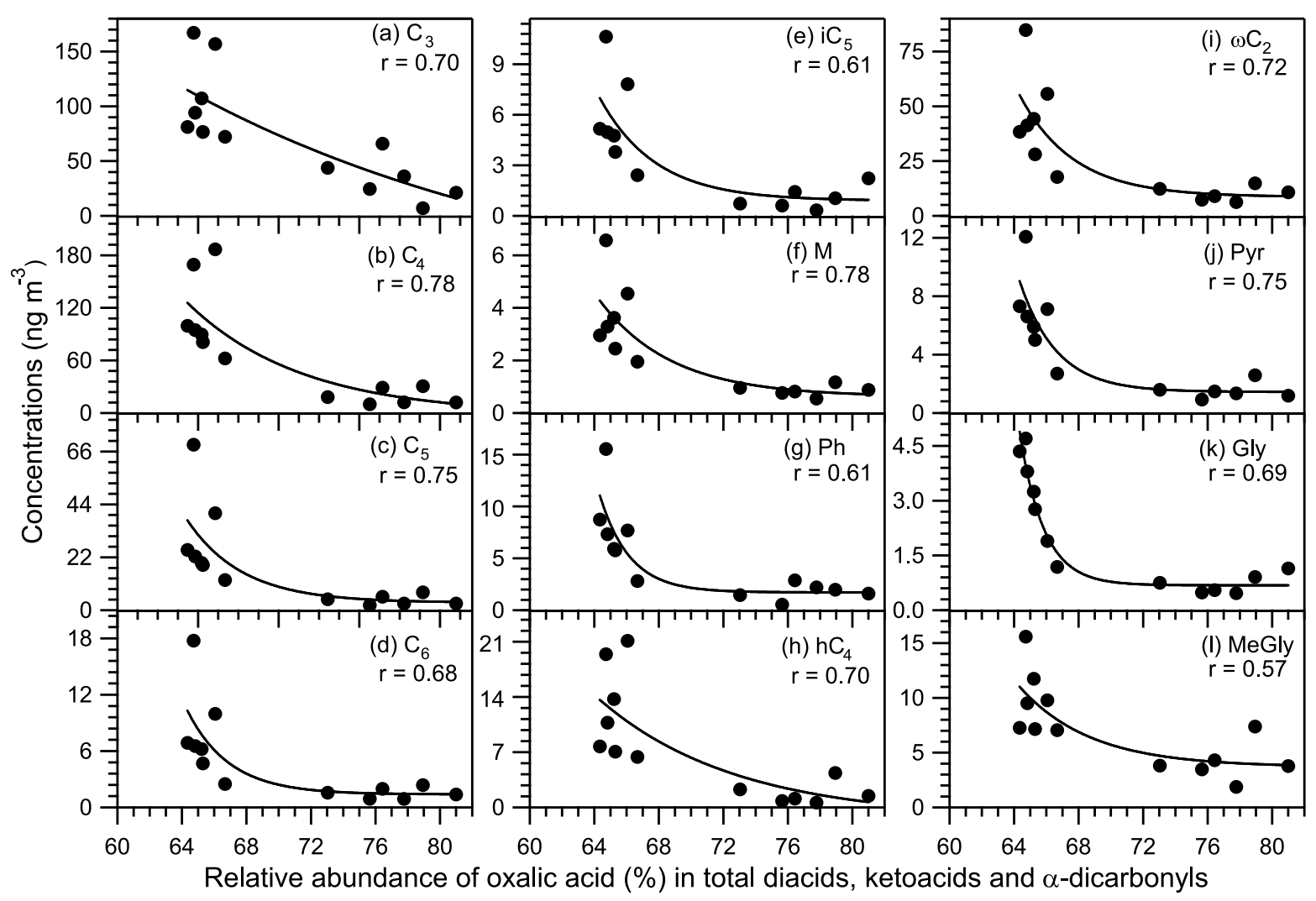

Figure 11. Summertime relations of relative abundances (\%) of oxalic acid $\left(\mathrm{C}_{2}\right)$ in detected molecular organics with concentrations of (a) malonic acid $\left(\mathrm{C}_{3}\right)$, (b) succinic acid $\left(\mathrm{C}_{4}\right)$, (c) glutaric acid $\left(\mathrm{C}_{5}\right)$, (d) adipic acid $\left(\mathrm{C}_{6}\right)$, (e) methylsuccinic acid $\left(\mathrm{iC}_{5}\right)$, (f) maleic acid $(\mathrm{M}),(\mathrm{g})$ phthalic acid $(\mathrm{Ph}),(\mathrm{h})$ malic acid $\left(\mathrm{hC}_{4}\right)$, (i) glyoxylic acid $\left(\omega \mathrm{C}_{2}\right)$, (j) pyruvic acid (Pyr), (k) glyoxal (Gly), and (l) methylglyoxal (MeGly). 


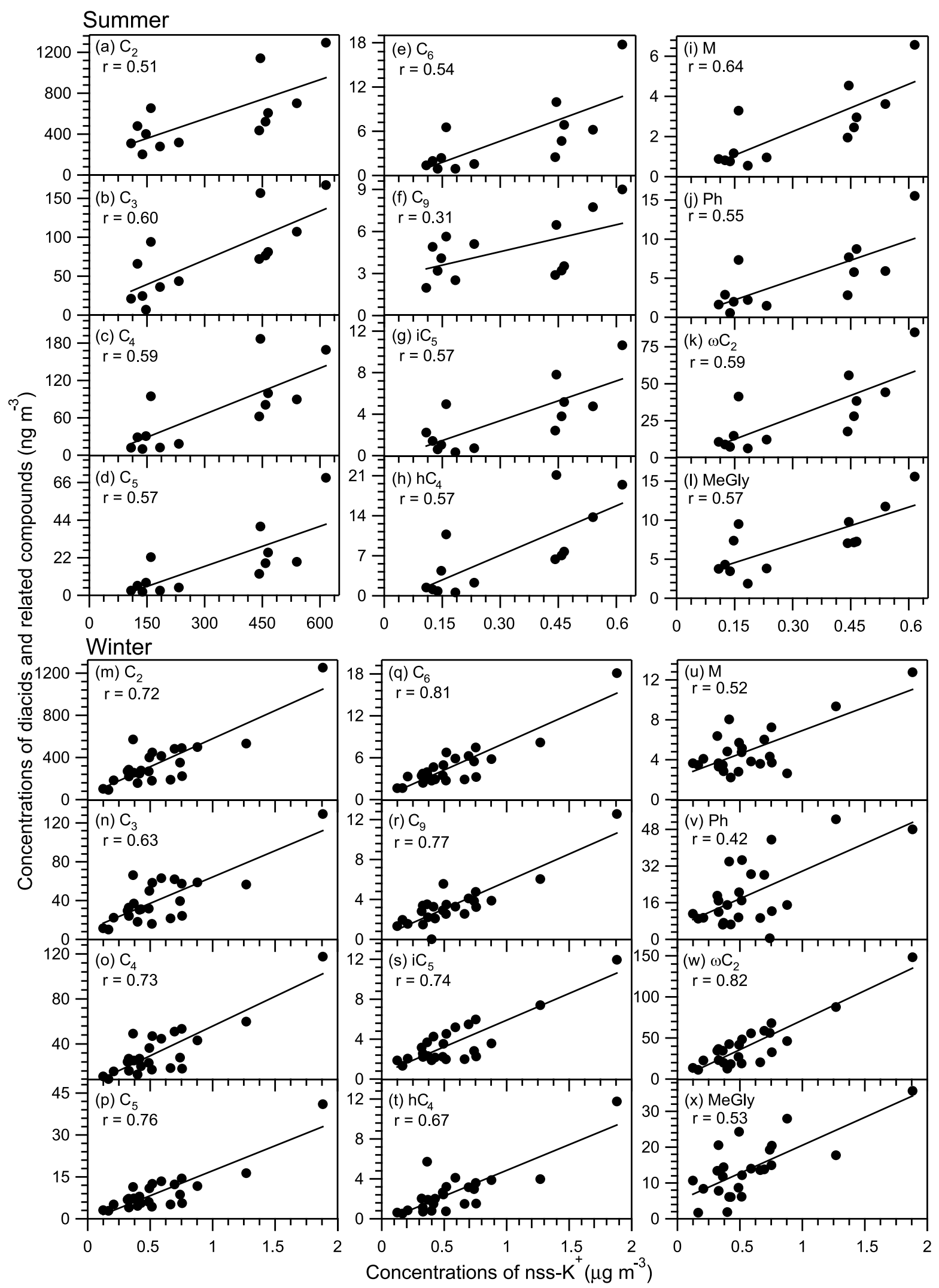

Figure 12. Summer- and wintertime relations between non-sea-salt $\mathrm{K}^{+}$and $(\mathrm{a}, \mathrm{m})$ oxalic acid $\left(\mathrm{C}_{2}\right)$, $(\mathrm{b}, \mathrm{n})$ malonic acid $\left(\mathrm{C}_{3}\right),(\mathrm{c}, \mathrm{o})$ succinic acid $\left(\mathrm{C}_{4}\right),(\mathrm{d}, \mathrm{p})$ glutaric acid $\left(\mathrm{C}_{5}\right),(\mathrm{e}, \mathrm{q})$ adipic acid $\left(\mathrm{C}_{6}\right),(\mathrm{f}, \mathrm{r})$ azelaic acid $\left(\mathrm{C}_{9}\right),(\mathrm{g}, \mathrm{s})$ isosuccinic acid $\left(\mathrm{iC}_{5}\right),(\mathrm{h}, \mathrm{t})$ malic acid $\left(\mathrm{hC} \mathrm{C}_{4}\right),(\mathrm{i}, \mathrm{u})$ maleic acid $(\mathrm{M}),(\mathrm{j}, \mathrm{v})$ phthalic acid $(\mathrm{Ph})$, $(\mathrm{k}, \mathrm{w})$ glyoxylic acid $\left(\omega \mathrm{C}_{2}\right)$, and $(1, \mathrm{x})$ methylglyoxal (MeGly). Non-sea-salt $\mathrm{K}^{+}$is calculated as total $\mathrm{K}^{+}$ minus $\mathrm{Na}^{+} \times 0.021$. 
Summer
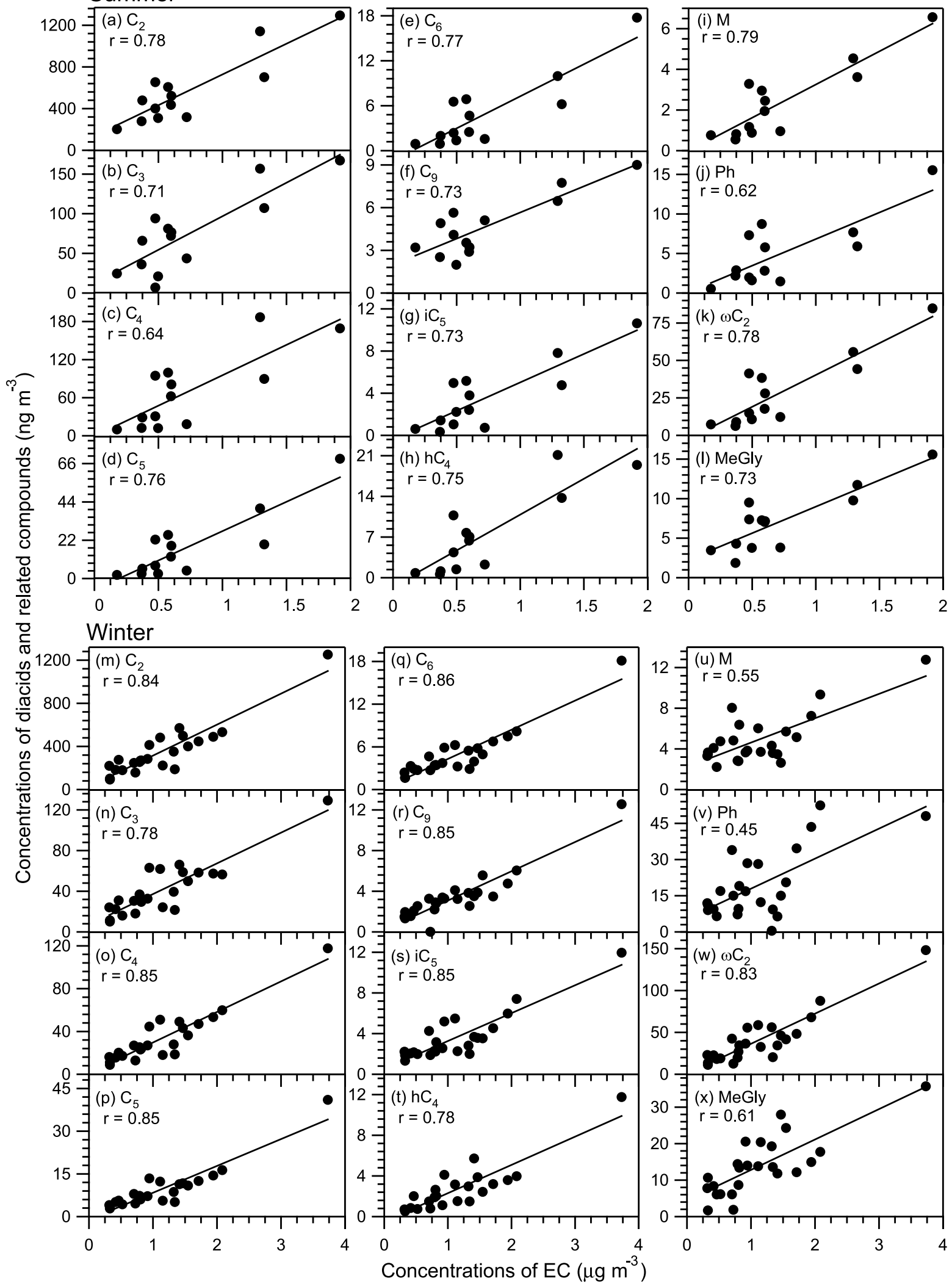

Figure 13. Summer- and wintertime relations between elemental carbon and $(\mathrm{a}, \mathrm{m})$ oxalic acid $\left(\mathrm{C}_{2}\right)$, $(\mathrm{b}, \mathrm{n})$ malonic acid $\left(\mathrm{C}_{3}\right),(\mathrm{c}, \mathrm{o})$ succinic acid $\left(\mathrm{C}_{4}\right),(\mathrm{d}, \mathrm{p})$ glutaric acid $\left(\mathrm{C}_{5}\right),(\mathrm{e}, \mathrm{q})$ adipic acid $\left(\mathrm{C}_{6}\right),(\mathrm{f}, \mathrm{r})$ azelaic acid $\left(\mathrm{C}_{9}\right),(\mathrm{g}, \mathrm{s})$ isosuccinic acid $\left(\mathrm{iC}_{5}\right),(\mathrm{h}, \mathrm{t})$ malic acid $\left(\mathrm{hC} \mathrm{C}_{4}\right),(\mathrm{i}, \mathrm{u})$ maleic acid $(\mathrm{M}),(\mathrm{j}, \mathrm{v})$ phthalic acid $(\mathrm{Ph})$, $(\mathrm{k}, \mathrm{w})$ glyoxylic acid $\left(\omega \mathrm{C}_{2}\right)$, and $(\mathrm{l}, \mathrm{x})$ methylglyoxal (MeGly). 
[31] It has been demonstrated that biomass burning is an important source of diacids and related compounds [Decesari et al., 2006; Falkovich et al., 2005; Kundu et al., 2010a]. In order to evaluate the impacts of biomass burning and combustion sources at Gosan, we draw scatterplots of biomass burning tracer (non-sea-salt $\mathrm{K}^{+}$) and combustion tracer (EC) with diacids and related compounds in Figures 12 and 13 , respectively. Although fair to good positive correlations were observed for diacids and related compounds with $\mathrm{K}^{+}$and $\mathrm{EC}$ in summer and winter, no statistically significant correlations were observed in spring and autumn. These results suggest an enhanced contribution of the combustion sources for diacids and related compounds and their precursors in summer and winter. The better correlations in winter suggest that biomass and fossil fuel combustion significantly contributes to the water-soluble organic species in Gosan aerosols. The weaker correlations in summer may suggest an importance of enhanced oceanic contribution and photochemical processing.

[32] Similar good correlations were also observed between secondary aerosol tracers $\left(\mathrm{SO}_{4}^{2-}\right.$ and $\left.\mathrm{NO}_{3}^{-}\right)$and diacids and related compounds only in summer $\left(\mathrm{r}^{2}=0.20\right.$ $0.79, n=13)$ and winter $\left(r^{2}=0.38-0.83, n=24\right.$; data are not shown). This again demonstrates that both emission and secondary production are important processes in Gosan aerosols. More tight relations between secondary tracers as well as combustion tracers and diacids and related compounds were observed in winter than in summer. This result can be interpreted by the presence of more specific sources for diacids and related compounds as well as their precursors in winter. As shown in Figure 4d, almost all air masses in winter are transported from northern China, where combustion of fossil fuel/biofuel is very common in cold winter (see http://www.bjstats.gov.cn). This again supports the idea that northern China is an important source region for winter aerosols at Gosan.

\section{Conclusions}

[33] Diacids and related compounds (ketoacids and $\alpha$ dicarbonyls) have been determined in atmospheric aerosol samples collected from April 2003 to April 2004 over Gosan in Jeju Island, Korea. The characteristic seasonal variations of diacids and related compounds were found at the Gosan site, which are associated with their different sources and photochemical processing. A year-round data set showed that oxalic acid $\left(\mathrm{C}_{2}\right)$ is the dominant species followed by malonic acid $\left(\mathrm{C}_{3}\right)$ in all seasons. This study demonstrates an enhanced photochemical formation and degradation of dicarboxylic acids and related compounds in summer. It also shows photochemical aging of organic aerosols during long-range transport from the East Asian continent to Gosan. Comparison of concentrations at the Gosan site with available data set in East Asian cities suggests that atmospheric transport of diacids and related compounds as well as their precursors from Chinese cities to Gosan is the most important source. These findings are consistent with seasonal variations of diacids and related compounds, whose concentrations maximized in winter and summer and correlated positively with combustion tracers $\left(\mathrm{K}^{+}\right.$and $\left.\mathrm{EC}\right)$ and secondary tracers $\left(\mathrm{SO}_{4}^{2-}\right.$ and $\left.\mathrm{NO}_{3}^{-}\right)$. We also found that the concentrations of these organics and combustion/secondary tracers are most tightly correlated in winter samples, demonstrating that Asian outflows from northeast China most likely affect the air quality of Gosan in Jeju Island and the surrounding ocean in the western North Pacific.

[34] Acknowledgments. This research was supported in part by the Japanese Ministry of Education, Science, Sport and Culture (MEXT) through grant-in-aid 14204025 and 17340166 and the Environment Research and Technology Development Fund (B-0903) of the Ministry of Environment, Japan. S.K. acknowledges financial support from the MEXT. The authors are grateful to NOAA Air Resources Laboratory (ARL) for allowing the installation of a registered version of Windowsbased HYSPLIT model.

\section{References}

Arimoto, R., R. A. Duce, J. M. Prospero, D. L. Savoie, R. W. Talbot, J. E. Dibb, B. G. Heikes, B. J. Ray, N. F. Lewis, and U. Tomza (1997), Comparisons of trace constituents from ground stations and the DC-8 aircraft during PEM-West B, J. Geophys. Res., 102, 28,539-28,550.

Baboukas, E. D., M. Kanakidou, and N. Mihalopoulos (2000), Carboxylic acids in gas and particulate phase above the Atlantic Ocean, J. Geophys Res., 105, 14,459-14,471.

Bandow, H., N. Washida, and H. Akimoto (1985), Ring cleavage reactions of aromatic hydrocarbons studied by FT-IR spectroscopy: I. Photooxidation of toluene and benzene in the $\mathrm{NO}_{\mathrm{x}}$-air system, Bull. Chem. Soc. Jpn., $58,2531-2540$.

Bunce, N. J., L. Liu, and J. Zhu (1997), Reaction of naphthalene and its derivatives with hydroxyl radicals in the gas phase, Environ. Sci. Technol., 31, 2252-2259.

Carlton, A. G., B. J. Turpin, K. E. Altieri, S. Seitzinger, A. Reff, H.-J. Lim, and B. Erven (2006), Atmospheric oxalic acid and SOA production from glyoxal: Results of aqueous photooxidation experiments, Atmos. Environ., 41, 7588-7602.

Carmichael, G. R., Y. Zhang, L.-L. Chen, S.-M. Hong, and H. Ueda (1996), Seasonal variation on aerosol composition at Cheju Island, Korea, Atmos. Environ., 30, 2407-2416.

Carmichael, G. R., M. S. Hong, H. Ueda, L. L. Chen, K. Murano, J. K. Park, H. Lee, Y. Kim, C. Kang, and S. Shim (1997), Aerosol composition at Cheju Island, Korea, J. Geophys. Res., 102, 6047-6061.

Chen, L.-L., et al. (1997), Influence of continental outflows on the aerosol composition at Cheju Island, South Korea, J. Geophys. Res., 102, 28,551-28,574.

Cruz, C. N., and S. N. Pandis (1997), A study of the ability of secondary organic aerosol to act as cloud condensation nuclei, Atmos. Environ., 31 , 2205-2214.

Decesari, S., et al. (2006), Characterization of the organic composition of aerosols from Rondônia, Brazil, during the LBA-SMOCC 2002 experiment and its representation through model compounds, Atmos. Chem. Phys., 6, 375-402.

Ervens, B., G. Feingold, G. J. Frost, and S. M. Kreidenweis (2004), A modeling study of aqueous production of dicarboxylic acids: 1. Chemical pathways and speciated organic mass production, J. Geophys. Res., 109, D15205, doi:10.1029/2003JD004387.

Falkovich, A. H., E. R. Graber, G. Schkolnik, Y. Rudich, W. Maenhaut, and P. Artaxo (2005), Low molecular weight organic acids in aerosol particles from Rondônia, Brazil, during the biomass-burning, transition and wet periods, Atmos. Chem. Phys., 5, 781-797.

Fisseha, R., J. Dommen, M. Sax, D. Paulsen, M. Kalberer, R. Maurer, F. Höfler, E. Weingartner, and U. Baltensparger (2004), Identification of organic acids in secondary organic aerosol and the corresponding gas phase from Chamber experiments, Anal. Chem., 76, 6535-6560.

Folkers, M., T. F. Mentel, and A. Wahner (2003), Influence of an organic coating on the reactivity of aqueous aerosols probed by heterogeneous hydrolysis of $\mathrm{N}_{2} \mathrm{O}_{5}$, Geophys. Res. Lett., 30(12), 1644, doi:10.1029/ 2003 GL017168.

Fraser, M. P., Z. W. Yue, R. J. Tropp, S. D. Kohl, and J. C. Chow (2002), Molecular composition of organic fine particulate matter in Houston, TX, Atmos. Environ., 36, 5751-5758.

Gao, S., D. A. Hegg, G. Frick, P. F. Caffrey, L. Pasternack, C. Cantrell, W. Sullivan, J. Ambrusko, T. Albrechcinski, and T. W. Kirchstetter (2001), Experimental and modeling studies of secondary organic aerosol formation and some applications to the marine boundary layer, J. Geophys. Res., 106(D21), 27,619-27,634.

Gao, S., D. A. Hegg, P. V. Hobbs, T. W. Kirchstetter, B. I. Magi, and M. Sadilek (2003), Water-soluble organic components in aerosols associ- 
ated with savanna fires in southern Africa: Identification, evaluation, and distribution, J. Geophys. Res., 108(D13), 8491, doi:10.1029 2002JD002324.

Hallquist, M., et al. (2009), The formation, properties and impact of secondary organic aerosol: Current and emerging issues, Atmos. Chem. Phys., 9, 5155-5236.

Hatakeyama, S., T. Tanonaka, J. Weng, H. Bandow, H. Takagi, and H. Akimoto (1985), Ozone-cyclohexene reaction in air: Quantitative analyses of particulate products and the reaction mechanism, Environ. Sci. Technol., 19, 935-942.

Ho, K. F., J. J. Cao, S. C. Lee, K. Kawamura, R. J. Zhang, J. C. Chow, and J. G. Watson (2007), Dicarboxylic acids, ketocarboxylic acids, and dicarbonyls in urban atmosphere of China, J. Geophys. Res., 112, D22S27, doi:10.1029/2006JD008011.

Hoell, J. M., D. D. Davis, S. C. Liu, R. Newell, M. Shipham, H. Akimoto, R. J. McNeal, R. J. Bendura, and J. W. Drewry (1996), Pacific Exploratory Mission-West A (PEM-West A): September-October 1991 , J. Geophys. Res., 101, 1641-1653.

Hoell, J. M., D. D. Davis, S. C. Liu, R. E. Newell, H. Akimoto, R. J. McNeal, and R. J. Bendura (1997), The Pacific Exploratory Mission-West Phase B February-March, 1994, J. Geophys. Res., 102, 28,223-28,239.

Huebert, B. J., T. Bates, P. B. Russel, G. Y. Shi, Y. J. Kim, K. Kawamura G. Carmichael, and T. Nakajima (2003), An overview of ACE-Asia Strategies for quantifying the relationships between Asian aerosols and their climate impacts, J. Geophys. Res., 108(D23), 8633, doi:10.1029/ 2003JD003550.

Ieda, T., Y. Kitamori, M. Mochida, R. Hirata, T. Hirano, K. Inukai, Y. Fujinuma, and K. Kawamura (2006), Diurnal variations and vertical gradients of biogenic volatile and semi-volatile organic compounds at the Tomakomai larch forest station in Japan, Tellus, Ser. B, 59, 177-186.

Jang, M., and S. R. McDow (1997), Products of benz[a]anthracene photodegradation in the presence of known organic constituents of atmospheric aerosols, Environ. Sci. Technol., 31, 1046-1053.

Kalberer, M., J. Yu, D. R. Cocker, R. C. Flagan, and J. H. Seinfeld (2000), Aerosol formation in the cyclohexene-ozone system, Environ. Sci. Technol., 34, 4894-4901.

Kawamura, K. (1993), Identification of $\mathrm{C}_{2}-\mathrm{C}_{10}$ w-oxocarboxylic acids, pyruvic acid, and $\mathrm{C}_{2}-\mathrm{C}_{3} \alpha$-dicarbonyls in wet precipitation and aerosol samples by capillary GC and GC-MS, Anal. Chem., 65, 3505-3511.

Kawamura, K., and R. B. Gagosian (1987), Implications of $\omega$-oxocarboxylic acids in the remote marine atmosphere for photo-oxidation of unsaturated fatty acids, Nature, 325, 330-332.

Kawamura, K., and K. Ikushima (1993), Seasonal changes in the distribution of dicarboxylic acids in the urban atmosphere, Environ. Sci. Technol., 27, 2227-2235.

Kawamura, K., and I. R. Kaplan (1987), Motor exhaust emission as a primary source of dicarboxylic acids in Los Angeles ambient air, Environ. Sci. Technol., 21, 105-110.

Kawamura, K., and F. Sakaguchi (1999), Molecular distributions of water soluble dicarboxylic acids in marine aerosols over the Pacific Ocean including tropic, J. Geophys. Res., 104, 3501-3509.

Kawamura, K., and K. Usukura (1993), Distribution of low molecular weight dicarboxylic acids in the North Pacific aerosol samples, J. Oceanogr., 49, 271-283.

Kawamura, K., and O. Yasui (2005), Diurnal changes in the distribution of dicarboxylic acids, ketocarboxylic acids and dicarbonyls in the urban Tokyo atmosphere, Atmos. Environ., 39, 1945-1960.

Kawamura, K., H. Kasukabe, O. Yasui, and L. A. Barrie (1995), Production of dicarboxylic acids in the arctic atmosphere at polar sunrise, Geophys. Res. Lett., 22, 1253-1256.

Kawamura, K., H. Kasukabe, and L. A. Barrie (1996), Source and reaction pathways of dicarboxylic acids, ketoacids, and dicarbonyls in artic aerosols at polar sunrise, Atmos. Environ., 30, 1709-1722.

Kawamura, K., N. Umemoto, M. Mochida, T. Bertram, S. Howell, and B. J. Huebert (2003), Water-soluble dicarboxylic acids in the tropospheric aerosols collected over east Asia and western North Pacific by ACE-Asia C-130 aircraft, J. Geophys. Res., 108(D23), 8639, doi:10.1029/ 2002JD003256.

Kawamura, K., M. Kobayashi, N. Tsubonuma, M. Mochida, T. Watanabe, and M. Lee (2004), Organic and inorganic compositions of marine aerosols from East Asia: Seasonal variations of water soluble dicarboxylic acids, major ions, total carbon and nitrogen, and stable $\mathrm{C}$ and $\mathrm{N}$ isotopic composition, in Geochemical Investigation in Earth and Space Science; A Tribute to Issac R. Kaplan, The Geochemical Society Special Publication Series, vol. 9, edited by R. J. Hill, pp. 243-265, Elsevier, Amsterdam, Netherlands.

Kerminen, V.-M., K. Teinila, R. Hillamo, and T. Makela (1999), Size segregated chemistry of particulate dicarboxylic acids in the Artic atmosphere, Atmos. Environ., 33, 2089-2100.
Kerminen, V.-M., C. Ojanen, T. Pakkanen, R. Hillamo, M. Aurela, and J. Merilainen (2000), Low-molecular weight dicarboxylic acids in an urban and rural atmosphere, J. Aerosol. Sci., 31, 349-362.

Khwaja, H. A. (1995), Atmospheric concentrations of carboxylic acids and related compounds at a semiurban site, Atmos. Environ., 29, 127-139.

Kim, J. Y., Y. S. Ghim, C. H. Song, S.-C. Yoon, and J. S. Han (2007), Seasonal characteristics of air masses arriving at Gosan, Korea, using fine particle measurements between November 2001 and August 2003, J. Geophys. Res., 112, D07202, doi:10.1029/2005JD006946.

Kim, K.-H., M. Lee, G. Lee, Y. P. Kim, Y.-H. Youn, J.-M. Oh (2002), Observations of aerosol-bound ionic composition at Cheju Island Korea, Chemosphere, 48, 317-327.

Kim, Y. P., S.-G. Shim, and K. C. Moon (1998), Monitoring of air pollutants at Kosan, Cheju Island, Korea, during March-April 1994, J. Appl. Meteorol., 37, 1117-1126.

Kundu, S., K. Kawamura, T. W. Andreae, A. Hoffer, and M. O. Andreae (2010a), Molecular distributions of dicarboxylic acids, ketocarboxylic acids and $\alpha$-dicarbonyls in biomass burning aerosols: Implications for photochemical production and degradation in smoke layers, Atmos. Chem. Phys., 10, 2209-2225.

Kundu, S., K. Kawamura, T. W. Andreae, A. Hoffer, and M. O. Andreae (2010b), Diurnal variation in the water-soluble inorganic ions, organic carbon and isotopic compositions of total carbon and nitrogen in biomass burning aerosols from the LBA-SMOCC campaign in Rondônia, Brazil, J. Aerosol Sci., 41, 118-133.

Lee, M., M. Song, K. J. Moon, J. S. Han, G. Lee, and K.-R. Kim (2007), Origins and chemical characteristics of fine aerosols during the northeastern Asia regional experiment (Atmospheric Brown Cloud-East Asia Regional Experiment 2005), J. Geophys. Res., 112, D22S29, doi:10.1029/2006JD008210.

Legrand, M., S. Preunkert, T. Oliveira, C. A. Pio, S. Hammer, A. Gelencsér, A. Kasper-Giebl, and P. Laj (2007), Origin of $\mathrm{C}_{2}-\mathrm{C}_{5}$ dicarboxylic acids in the European atmosphere inferred from year-around aerosol study conducted at a west-east transect, J. Geophys. Res., 112, D23S07, doi:10.1029/2006JD008019.

Li, S. M., and J. W. Winchester (1993), Water-soluble organic constituents in Arctic aerosols and snow pack, Geophys. Res. Lett., 20, 45-48.

Lim, H. J., and B. J. Turpin (2002), Origins of primary and secondary organic aerosol in Atlanta: Results of time-resolved measurements during the Atlanta Supersite experiment, Environ. Sci. Technol., 36, 4489-4496.

Lim, H.-J., A. G. Carlton, and B. J. Turpin (2005), Isoprene forms secondary organic aerosol through cloud processing: Model simulations, Environ. Sci. Technol., 39, 4441-4446, doi:10.1021/es048039h.

Limbeck, A., H. Pauxbaum, L. Otter, and M. C. Scholes (2001), Semivolatile behaviour of dicarboxylic acids and other polar organic species at a rural background site (Nylsvley, RSA), Atmos. Environ., 35, 1853-1862.

Matsunaga, S., K. Kawamura, T. Nakatsuka, and N. Ohkouchi (1999), Preliminary study on laboratory photochemical formation of low molecular weight dicarboxylic acids from unsaturated fatty acid (oleic acid), Res. Org. Geochem., 14, 19-25.

Mayol-Bracero, O. L., P. Guyon, B. Graham, G. Roberts, M. O. Andreae, S. Decesari, M. C. Facchini, S. Fuzzi, and P. Artaxo (2002), Water soluble organic compounds in biomass burning aerosols over Amazonia 2: Apportionment of the chemical composition and importance of the polyacidic fraction, J. Geophys. Res., 107(D20), 8091, doi:10.1029/ 2001JD000522.

Mészáros, E., T. Barcza, A. Gelencsér, J. Hlavay, G. Y. Kiss, Z. Krivácsy, A. Molnár, and K. Ployák (1997), Size distributions of inorganic and organic species in the atmospheric aerosol in Hungary, J. Aerosol. Sci. 28, 1163-1175.

Miyazaki, Y., Y. Kondo, S. Han, M. Koike, D. Kodama, Y. Komazaki, H. Tanimoto, and H. Matsueda (2007), Chemical characteristics of water-soluble organic carbon in the Asian outflow, J. Geophys. Res., 112, D22S30, doi:10.1029/2007JD009116.

Miyazaki, Y., S. G. Aggarwal, K. Singh, P. K. Gupta, and K. Kawamura (2009), Dicarboxylic acids and water-soluble organic carbon in aerosols in New Delhi, India, in winter: Characteristics and formation processes, J. Geophys. Res., 114, D19206, doi:10.1029/2009JD011790.

Mochida, M., A. Kawabata, K. Kawamura, H. Hatsushika, and K. Yamazaki (2003a), Seasonal variation and origins of dicarboxylic acids in the marine atmosphere over the western North Pacific, J. Geophys. Res., 108(D6), 4193, doi:10.1029/2002JD002355.

Mochida, M., K. Kawamura, N. Umemoto, M. Kobayashi, S. Matsunaga, H.-J. Lim, B. J. Turpin, T. S. Bates, and B. R. T. Simoneit (2003b), Spatial distributions of oxygenated organic compounds (dicarboxylic acids, fatty acids, and levoglucosan) in marine aerosols over the western Pacific and off the coast of East Asia: Continental outflow of organic aerosols 
during the ACE-Asia campaign, J. Geophys. Res., 108(D23), 8638, doi:10.1029/2002JD003249.

Park, M. H., Y. P. Kim, C.-H. Kang, and S.-G. Shim (2004), Aerosol composition change between 1992 and 2002 at Gosan, Korea, J. Geophys. Res., 109, D19S13, doi:10.1029/2003JD004110.

Pradeep Kumar, P., K. Broekhuizen, and J. P. D. Abbatt (2003), Organic acids as cloud condensation nuclei: Laboratory studies of highly soluble and insoluble species, Atmos. Chem. Phys. Disc., 3, 949-982.

Ray, J., and S. R. Mcdow (2005), Dicarboxylic acid concentration trends and sampling artifacts, Atmos. Environ., 39, 7906-7919.

Rogge, W. F., L. M. Hildemann, M. A. Mazurek, G. R. Cass, and B. R. T. Simoneit (1991), Sources of fine organic aerosol, 1, Charbroilers and meat cooking operations, Environ. Sci. Technol., 25, 1112-1125.

Satsumabayashi, H., H. Kurita, Y. Yokouchi, and H. Ueda (1990), Photochemical formation of particulate dicarboxylic acids under long range transport in central Japan, Atmos. Environ., Part A, 24, 1443-1450.

Schauer, J. J., M. J. Kleeman, G. R. Cass, and B. R. T. Simoneit (1999), Measurement of emissions from air pollution sources, $1, \mathrm{C}_{1}$ through $\mathrm{C}_{29}$ organic compounds from meat charboiling, Environ. Sci. Technol., $33,1566-1577$.

Schauer, J. J., M. J. Kleeman, G. R. Cass, and B. R. T. Simoneit (2001), Measurement of emissions from air pollution sources. 3. $\mathrm{C}_{1}-\mathrm{C}_{29}$ organic compounds from fireplace combustion of wood, Environ. Sci. Technol., $35,1716-1728$

Schauer, J. J., M. J. Kleeman, G. R. Cass, and B. R. T. Simoneit (2002), Measurement of emissions from air pollution sources. 5. $\mathrm{C}_{1}-\mathrm{C}_{32}$ organic compounds from gasoline-powered motor vehicles, Environ. Sci. Technol., 36, 1169-1180.

Stephanou, E. G., and N. Stratigakis (1993), Oxocarboxylic and $\alpha, \omega$-dicarboxylic acids: Photooxidation products of biogenic unsaturated fatty acids present in urban aerosols, Environ. Sci. Technol., 27, 1403-1407.
Stockwell, W. R., F. Kirchner, M. Kuhn, and S. Seefeld (1997), A new mechanism for regional atmospheric chemistry modeling, J. Geophys. Res., 102, 25,847-25,879.

Strader, R., F. Lurmann, and S. N. Pandis (1999), Evaluation of secondary organic aerosol formation in winter, Atmos. Environ., 33, 4849-4863.

Topping, D., H. Coe, G. McFiggans, R. Burgess, J. Allan, M. R. Alfarra, K. Bower, T. W. Choularton, S. Decesari, and M. C. Facchini (2004), Aerosol chemical characteristics from sampling conducted on the island of Jeju, Korea, during ACE Asia, Atmos. Environ., 38, 2111-2123.

Wang, G., K. Kawamura, and M. Lee (2009), Comparison of organic compositions in dust storm and normal aerosol samples collected at Gosan, Jeju Island, during spring, Atmos. Environ., 43, 219-227.

Wang, H., K. Kawamura, and K. Yamazaki (2006), Water-soluble dicarboxylic acids, ketoacids and dicarbonyls in the atmosphere over the Southern Ocean and Western North Pacific, J. Atmos. Chem, 53, 43-61.

Warneck, P. (2003), In-cloud chemistry opens pathway to the formation of oxalic acid in the marine atmosphere, Atmos. Environ., 37, 2423-2427.

Yamasoe, M. A., P. Artaxo, A. H. Miguel, and A. G. Allen (2000), Chemical composition of aerosol particles from direct emissions of vegetation fires in the Amazon Basin: Water-soluble species and trace elements, Atmos. Environ., 34, 1641-1653.

Yang, H., J. Xu, W. Wu, C. H. Wan, and J. Z. Yu (2004), Chemical characterization of water-soluble organic aerosols at Jeju Island collected during ACE-Asia, Environ. Chem., 1, 13-17, doi:10.1071/EN04006.

K. Kawamura and S. Kundu, Institute of Low Temperature Science, Hokkaido University, Sapporo 060-0819, Japan. (kawamura@lowtem. hokudai.ac.jp)

M. Lee, Department of Earth and Environmental Sciences, Korea University, Seoul 136-701, South Korea. 